\title{
IMPROVING ACCESS TO THE GREEN CLIMATE FUND: HOW THE FUND CAN BETTER SUPPORT DEVELOPING COUNTRY INSTITUTIONS
}

\section{EXECUTIVE SUMMARY}

\section{Highlights}

The Green Climate Fund (GCF, or "the Fund") is a globally important source of finance for paradigm shifting projects in developing countries that address climate goals.

- Central to the GCF's formation is an emphasis on providing funds directly to developing country institutions versus through international organizations. Through "direct access," it seeks to fund a diverse set of stakeholders including public, private, and nongovernmental organizations from developing countries, using a variety of financial instruments including grants, loans, equity, and guarantees.

- Sixty-two developing country institutions have received accreditation, but 42 of these entities have yet to receive project funding.

- The GCF has launched several initiatives to support accredited developing country institutions-known as Direct Access Entities-with project development and approval including the Readiness Programme, the Project Preparation Facility, the Simplified Approval Process (SAP), and the Enhancing Direct Access pilot, but these are not yet delivering sufficiently to meet the need.

There are a number of steps the GCF can take to support Direct Access Entities and thus expand the range of entities that receive project funding.

\section{CONTENTS}

Executive Summary .1

1. Introduction ...................................... 3

2. Context: Direct Access at the

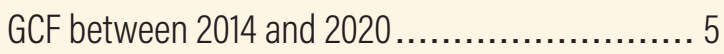

3. Successes and Challenges

in GCF Support to Entities Seeking

Access to the Fund ................................ 9

4. Recommendations ...............................20

Appendix A. List of Stakeholders Interviewed ........23

Glossary ........................................25

Endnotes........................................... 26

Bibliography ..................................26

Working Papers contain preliminary research, analysis, findings, and recommendations. They are circulated to stimulate timely discussion and critical feedback, and to influence ongoing debate on emerging issues. Working papers may eventually be published in another form and their content may be revised.

Suggested Citation: Caldwell, M., and G. Larsen. 2021. "Improving Access to the Green Climate Fund: How the Fund Can Better Support Developing Country Institutions” Working Paper. Washington, DC: World Resources Institute. Available online at doi.org/10.46830/wriwp.19.00132. 


\section{Background}

The GCF is the single largest source of public climate finance today. It is crucial to global efforts that developing countries be able to finance low-carbon, climate-resilient development. The Fund enables a wide variety of institutions-including governmental, private, and nongovernmental-to receive access to finance for mitigation and adaptation. This approach has opened the door to the potential for a more equitable, efficient, and transformative use of climate funds. Yet the high level of interest in the Fund, combined with the GCF's current system to facilitate access to funding, has led to bottlenecks and frustration for countries trying to access financing.

\section{One of the more innovative and notable pieces} of the GCF's funding structure is its direct access modality. Direct access allows entities from developing countries that have met a set of accreditation criteria to access funding directly from the GCF, without going through an international institution as they would need to do at most other multilateral climate funds. Today, the entities that have received direct access accreditation include both national and regional governments, private institutions, and nongovernmental organizations. Since beginning to accredit entities in 2015, the GCF has accredited 62 (60 percent) Direct Access Entities and 41 (40 percent) International Accredited Entities (international institutions based in developed countries). Despite the relatively large number of Direct Access Entities that have been accredited, 42 of them (67 percent) have yet to receive project approval. The reasons for this are several, but are generally associated with the significant effort and funding required to shepherd projects from initial idea into a full project proposal.

\section{About This Working Paper}

This paper reviews how the GCF has supported the ability of a variety of institutions to access finance through its "direct access" modality and recommends key changes it can make to improve this system. Our findings are based on interviews with representatives from national, regional, and international entities accredited to the GCF, National Designated Authorities (the government authorities responsible for coordinating access to GCF funds), and members of the GCF Secretariat. The authors also reviewed GCF publications including board documents, manuals, and policies along with other academic literature on GCF's operations. All data reported in this paper are as of the GCF's 27th board meeting on November 10-13, 2020.
Among Direct Access Entities, there is a diversity in size, scope, and type of entity, which means that some of the issues and challenges they face differ. Nonetheless, interviews with entities revealed that they also encounter common problems both internally and with the GCF when trying to get projects approved.

\section{Key Findings}

The GCF has put in place policies and programs to help ensure that a diverse range of actors are able to access GCF funding. These include the Readiness Programme, the Project Preparation Facility, the Simplified Approval Process, and Enhancing Direct Access pilot.

This paper looks at how these four policies and programs are succeeding to date-or not-and provides recommendations for how to improve their effectiveness. Our recommendations are in line with the GCF's updated strategic plan for 2020-2023 approved in November 2020. We found the following:

The GCF's Readiness Programme provides assistance to entities seeking accreditation and project funding. However, its focus on National Designated Authorities, inability to cover key costs such as staff time, and somewhat cumbersome approval process make it unable to fully meet the needs of Direct Access Entities.

The GCF's Project Preparation Facility provides funding to entities developing project documentation. However, the facility does not fully cover the cost of developing concept notes and is not sufficiently reaching entities that have not had previous projects approved by the GCF.

The GCF developed a Simplified Approval Process for projects under $\$ 50$ million ( $\$ 10$ million GCF maximum contribution) with low social and environmental risks. This process has not been simplified to a point where access is markedly faster or less burdensome than going through a full proposal process.

The GCF's Enhancing Direct Access window of finance has approved only two projects during the pilot's first five years. However, the underlying idea of devolving additional decision-making to the Direct Access Entity and other stakeholders remains very popular. 


\section{Key Recommendations for the GCF}

\section{Improve funding to help entities identify and develop projects:}

Provide "kick-off" funding of around $\$ 100,000-$ 250,000 automatically upon accreditation to support project identification and concept note development.

- Reorganize the structure of support by combining and streamlining readiness and project preparatory funding.

- Allow Direct Access Entities to cover more of their own costs associated with the time spent on project identification and development.

- In addition to providing financial support, continue to ensure that Direct Access Entities have access to experts who understand the unique requirements of the GCF.

\section{Improve the project approval process:}

Streamline the review process and reduce the proposal requirements for the Simplified Approval Process. The GCF should also reduce the number of questions in the SAP proposal.

- Restructure the Enhancing Direct Access pilot by removing the funding cap and clarifying how projects funded through this modality differ from projects funded through the normal project approval process.

\section{INTRODUCTION}

The Green Climate Fund (GCF, or "the Fund") is a central institution in the global architecture of international climate finance. Set up in 2010 under the United Nations Framework Convention on Climate Change, the GCF is an important cornerstone in international climate negotiations. The multilateral fund channels finance to developing countries to help them implement paradigm-shifting climate action.

The GCF is the largest single source of concessional climate finance today. In 2014, the GCF launched its first resource mobilization, raising $\$ 10.3$ billion in funds, and in 2019 the Fund had its first round of replenishment with $\$ 9.9$ billion in pledges. This contrasts with the Global Environment Facility, which has received $\$ 4.1$ billion for 2018-2022 and the Climate Investment Funds' $\$ 8.3$ billion since 2009. The GCF is also the only large-scale climate fund that has a target to ensure a 50:50 balance between funding approved for adaptation and mitigation (on grant-equivalent terms). Successful operation of the GCF is critical to helping countries less responsible for the climate crisis develop along a climate-compatible trajectory.

As the GCF is the largest source of concessional finance, expectations are high regarding the impact that projects will have on creating transformational change in developing countries. There is at times a perceived tension between the desire for large multi-country projects that deliver high greenhouse gas (GHG) reductions and the focus of the Fund on country ownership and adaptation needs. This perceived trade-off does not always reflect the reality of what is happening in projects or the ability that direct access has to deliver impact.

\section{The Importance of Direct Access}

When the GCF was established in 2010, proponents of the Fund, including developing country representatives and other supporters, advocated for direct access to become a central pillar so that developing countries could access resources from the GCF without having to go through an international entity as they would need to do at most other multilateral climate funds (see Figure 1).

As stated in the GCF's governing instrument, direct access was created with a "view to enhancing country ownership of projects and programmes" (GCF 2011). Country ownership was viewed as a right that developing countries had to govern their own resources and activities within their borders. As a board member stated at the board's eighth meeting: "direct access is important to incentivize and empower developing countries to use their own skills and capacities to shift the business models of existing agencies to be more responsive to the needs of developing countries" (GCF 2014b).

Direct access was also introduced to support cost effectiveness and efficiency in delivering financial resources to the intended beneficiaries. It allows funds to flow directly to accredited institutions in recipient countries (referred to as Direct Access Entities) instead of via international organizations, which can also be accredited to the GCF. For example, under direct access, the administrative fees that Accredited Entities collect, which range from 4 to 10 percent, go to institutions within the recipient country (or region) instead of staff at an international organization.

Finally, direct access proponents view it as a way to drive transformational impact in key institutions in developing countries. Meeting the GCF's requirements and accessing GCF funds can provide an opportunity for developing 


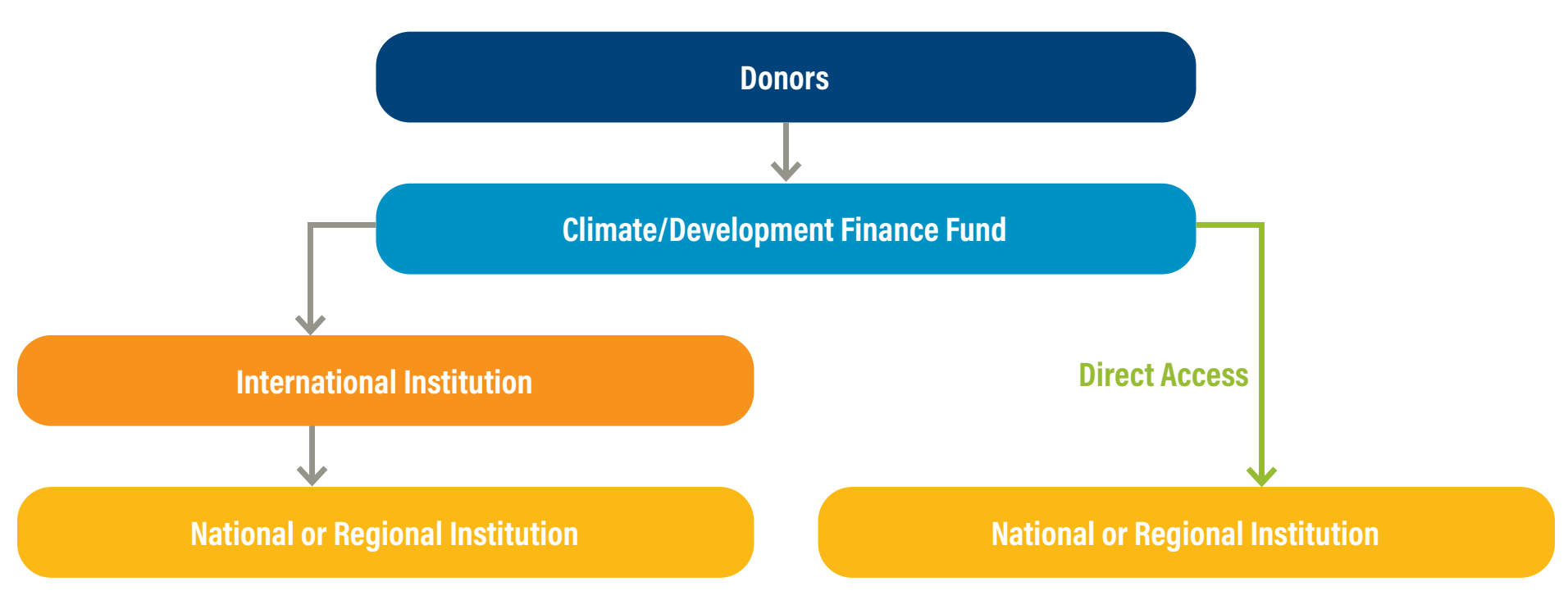

Source: Authors.

country institutions to strengthen their internal systems and more effectively integrate climate change throughout their operations. It could also amplify the work of those domestic entities already acting on climate change by granting them access to greater resources and influence.

This paper seeks to answer the following question: How can the GCF improve its support for Direct Access Entities to better ensure that a diverse set of organizations can better obtain access to project funding? To do so, the paper provides an overview of the four main ways in which the GCF has sought to enable direct access to funding-the Readiness Programme, Project Preparation Facility (PPF), Simplified Approval Process (SAP), Enhancing Direct Access pilot-and the successes and failures of these support mechanisms. It then provides recommendations for how the GCF can improve its approach to supporting access to the Fund for entities from developing countries, especially smaller institutions with limited resources.

\subsection{Methodology}

This paper is based on semi-structured interviews with representatives from 43 Direct Access Entities, 5 International Accredited Entities, 11 National Designated Authorities (NDAs), and 6 departments of the GCF Secretariat (Division of Country Programming, Division of Private Sector Facility, Division of Mitigation and Adaptation, Office of Portfolio Management, Office of Risk Management, and Compliance). Interviews took place between December 2019 and August 2020.
For Accredited Entities and National Designated Authorities (the government authorities responsible for coordinating access to GCF funds), interview questions centered on the interviewees' experiences with direct access and the GCF and recommendations for improvement. Questions for the Secretariat focused on specific policies, procedures, and examples. Interview data were collected in an online database.

In addition to conducting interviews, the authors pulled information from publicly available GCF reports, policies, templates, board discussions, and project documents. We analyzed information on the types of entities and their accreditation levels along with data on projects that have been financed, comparing them across impact categories, types of finance, and other metrics. All data reported in this paper are as of the GCF's 27th board meeting on November 10-13, 2020. Unless otherwise noted throughout the paper, all quantitative data come from Green Climate Fund publications and sources.

This paper builds upon a working paper from 2015 that reviewed entities' experiences with direct access to the Adaptation Fund and GCF at that time, which placed more emphasis on the accreditation process (see Masullo et al. 2015). Once more projects have reached completion, we recommend that more studies be done on the impact that direct access projects have within countries. Project evaluations will be valuable for building a more complete understanding of the role of direct access. 


\section{CONTEXT: DIRECT ACCESS AT THE GCF BETWEEN 2014 AND 2020}

Prior to the GCF, the Adaptation Fund and (to a far lesser extent) the Global Environment Facility were the first climate finance institutions to allow direct access for developing country institutions in addition to providing funds to international institutions. The GCF's direct access approach also builds on experiences at the Global Fund to Fight AIDS, Tuberculosis and Malaria as well as the GAVI Alliance, which similarly rely at times on national institutions to help oversee funding flows, in this case for health finance (UNFCCC 2011).

Today, the GCF is implementing direct access at a much larger scale and for a much broader range of activities than any other climate fund. All entities that want to receive funding straight from the GCF must first be accredited. The accreditation process aims to ensure that entities have sufficient experience and capacity to properly manage and deploy funding received. Once entities have received accreditation, they are then able to access funding for projects. Accreditation lasts for five years, at which point entities must be reaccredited.

\section{High Degree of Interest in Direct Access}

As of November 2020, 62 developing country entities had been accredited by the GCF while an additional 75 developing country entities had started the accreditation process (including those yet to pay the accreditation fees necessary to start Stage I of the process). In total, 235 organizations (including those accredited, seeking accreditation, and yet to submit an application for accreditation) have been nominated for direct access accreditation to the GCF by National Designated Authorities in 97 countries (GCF 2020d). The accredited Direct Access Entities are of a variety of sizes and institution types, from smaller nongovernmental organizations (NGOs) with limited access to human and financial resources, to ministries and government agencies and large national and regional development banks (see Table 1). In addition, the Fund has accredited 41 international entities, including United Nations agencies, multilateral development banks, private sector entities, and international NGOs, among others. The Fund thus has the potential to provide resources to a broad range of actors in developing countries seeking to act on climate change.

Table 1 | Number of Direct Access Entities by Category

\begin{tabular}{|c|c|c|}
\hline ENTITY & $\begin{array}{l}\text { NUMBER OF } \\
\text { ENTITIES }\end{array}$ & EXAMPLES \\
\hline $\begin{array}{l}\text { Government ministries } \\
\text { and agencies }\end{array}$ & 11 & $\begin{array}{l}\text { - Ministry of Health and the Environment (Antigua and Barbuda) } \\
\text { - National Environment Management Authority (Kenya) } \\
\text { - Ministry of Environment (Rwanda) }\end{array}$ \\
\hline Private for-profit & 14 & $\begin{array}{l}\text { - XacBank (Mongolia) } \\
\text { - Ecobank Ghana Limited (Ghana) } \\
\text { - JS Bank Limited (Pakistan) }\end{array}$ \\
\hline $\begin{array}{l}\text { Semi-public } \\
\text { institutions }\end{array}$ & 18 & $\begin{array}{l}\text { - Fonds National pour L'Environnement (Benin) } \\
\text { - Environmental Investment Fund (Namibia) } \\
\text { - Centre de Suivi Ecologique (Senegal) }\end{array}$ \\
\hline $\begin{array}{l}\text { National or regional } \\
\text { development banks }\end{array}$ & 13 & $\begin{array}{l}\text { - Development Bank of Southern Africa (South Africa) } \\
\text { - Corporación Andina de Fomento (Venezuela) } \\
\text { - Caribbean Development Bank (Barbados) }\end{array}$ \\
\hline Nonprofit & 6 & $\begin{array}{l}\text { - Fundación Avina (Panama) } \\
\text { - Secretariat of the Pacific Regional Environment Programme (Samoa) } \\
\text { - Micronesia Conservation Trust (Micronesia) }\end{array}$ \\
\hline
\end{tabular}


When designing the rules governing access to GCF funds, the board recognized a need to tailor requirements to reflect some of the differences between entities seeking funding. As a result, the GCF took a "fit for purpose" approach to accreditation (GCF 2014a). The approach created accreditation tiers to account for differences in entities' sizes and experiences. Entities can be accredited for projects of different sizes (from under $\$ 10$ million to over \$250 million), level of environmental and social risk (Categories A, B, or C; see Figure 3), and modality for financing mechanisms (project management; grant award; or on-lending/blending for loans, equity, and/or guarantees).

To date, around 61 percent of Direct Access Entities have been accredited to the micro (under $\$ 10$ million) or small (under $\$ 50$ million) categories (see Figure 2). Around 70 percent have been accredited for projects with medium levels of environmental or social risk (Category C; see Figure 3). Around 61 percent of entities are accredited for on-granting and around 50 percent for on-lending (see Table 2).

Most Direct Access Entities interviewed expressed the opinion that the GCF's accreditation process was difficult but ultimately useful to their organization as an exercise in assessing and strengthening their systems for managing and deploying funds. For instance, to achieve accreditation many institutions have improved their systems for managing fiduciary and operational risks. As an example, Fonds National pour L'Environnement in Benin reports that the GCF accreditation process motivated the bank
Figure 2 | Direct Access Entities by Maximum Size of Projects Allowed

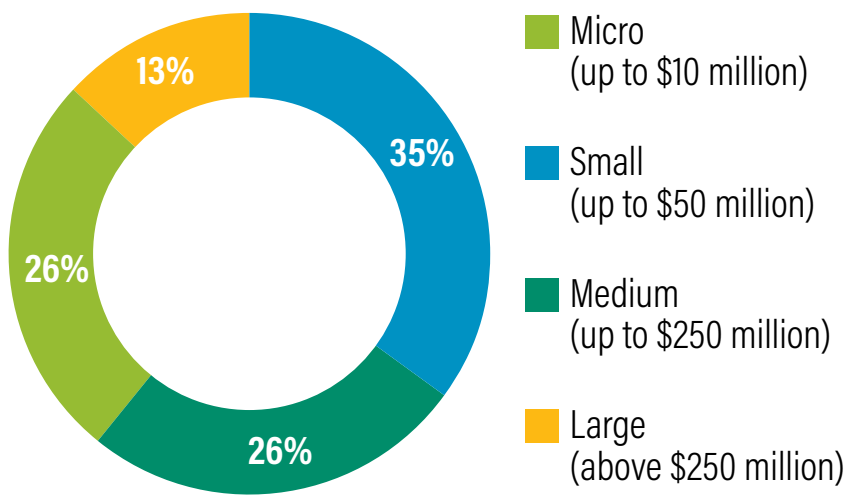

Source: Green Climate Fund. n.d. "About Us: Partners." Accessed February 1, 2021. https://www. greenclimate.fund/about/partners/ae.

Figure 3 | Direct Access Entities by Maximum Level of Environmental and Social Risk Allowed

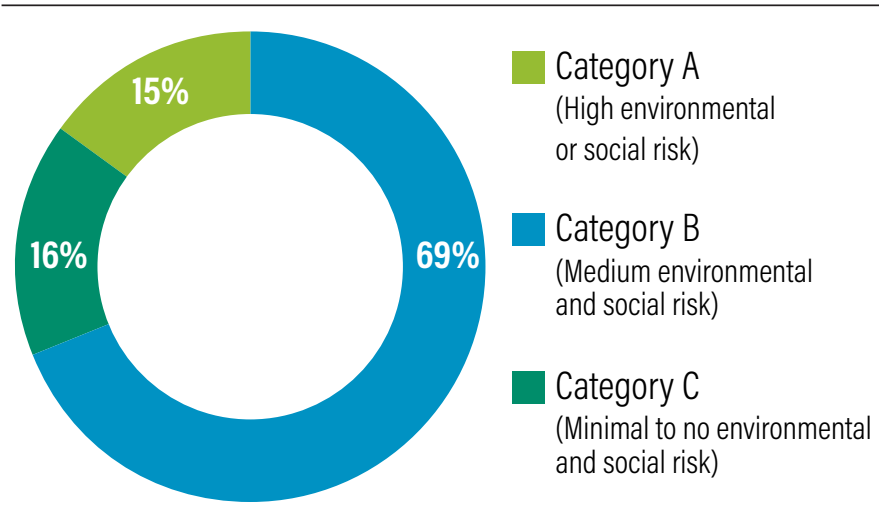

Source; Green Climate Fund. n.d. "About Us: Partners." Accessed February 1, 2021. https://www. greenclimate.fund/about/partners/ae.

Table 2 | Direct Access Entities by Type of Fiduciary Standard

FIDUCIARY STANDARD

Basic

Project management

Grant award

\begin{tabular}{|c|c|c|}
\hline \multirow{4}{*}{ On-lending/Blending } & Loan & 31 \\
\hline & Equity & 18 \\
\hline & Guarantee & 21 \\
\hline & Blending & 31 \\
\hline
\end{tabular}

Note: All Direct Access Entities have basic accreditation. In addition, they can have accreditation for one or more of the other fiduciary standards.

NUMBER OF DIRECT ACCESS ENTITIES

62

55

38

Source: Green Climate Fund. n.d. "About Us: Partners." Accessed February 1, 2021. https://www.greenclimate.fund/about/partners/ae. 
to put in place a number of new processes, including a system for categorizing and managing environmental and social risk and new policies for encouraging gender equity, combatting money laundering, managing conflicts of interest, and ensuring sound procurement.

\section{More than Two-Thirds of Direct Access Entities Have Not Yet Reached Project Approval}

Despite the positive progress that direct access has accomplished to date, the data show room for improvement. For example, more than two-thirds of Direct Access Entities (42 entities) have yet to have a project approved (see Figure 4 and Figure 5). There are eight Direct Access Entities accredited from 2015 to 2016 with no projects approved that are up for re-accreditation in 2021. The rate of project approvals has moreover dropped, with Direct Access Entities receiving fewer approvals as a percentage of the total in 2020 (22 percent) than during the GCF's initial year (43 percent) (see Figure 6). By comparison, a little over half of International Accredited Entities (23 entities) have had projects approved. As a result, international entities make up over 80 percent of the funded projects by number and 82 percent of the total dollar value of approved finance (see Figure 7).

For those Direct Access Entities with projects approved, it has taken them slightly less time, on average, to go from accreditation to project approval (564 days) compared with International Accredited Entities (627 days), although this average is impacted by one Direct Access Entity (Xacbank), which achieved project approval exceptionally fast in only 41 days. The average is also impacted by the number of Direct Access Entities without project approvals.
Figure 4 | Direct and International Entities: Number of Entities versus Number of Projects Approved
Number of accredited entities approved projects
Number of

150

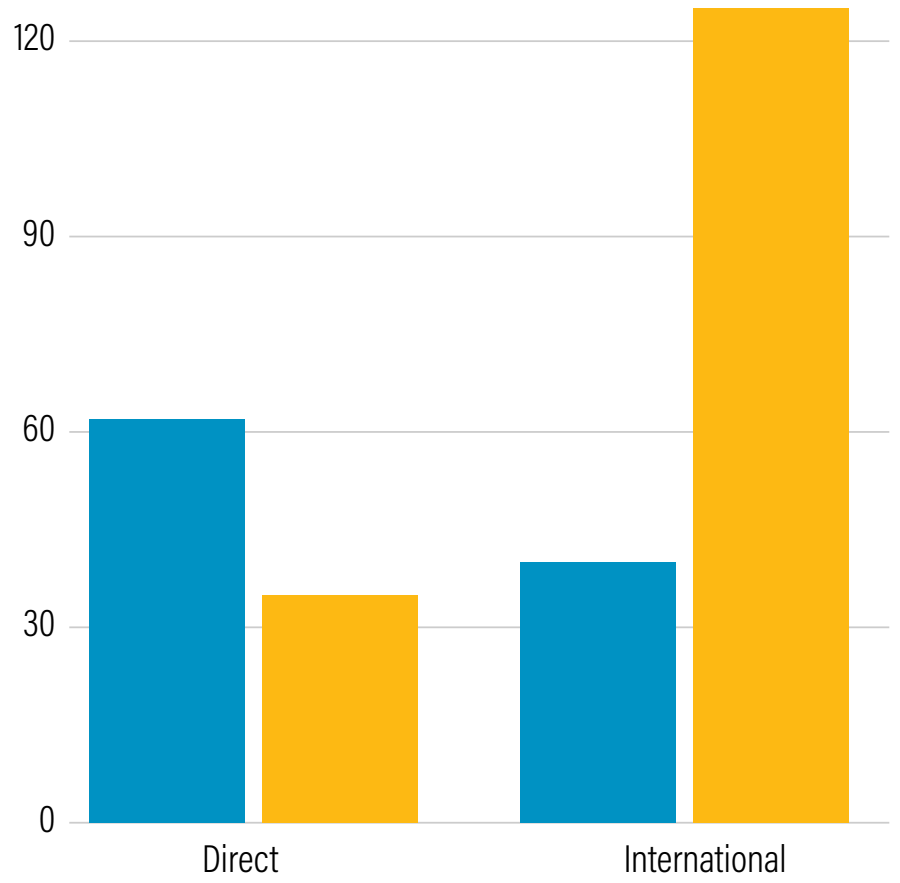

Sources: Green Climate Fund. n.d. "About Us: Partners." Accessed February 1, 2021. https:// www.greenclimate.fund/about/partners/ae; Green Climate Fund. n.d. "Projects and Programmes: Project Portfolio." Accessed February 1, 2021. https://www.greenclimate.fund/ projects.
DIRECT ACCESS

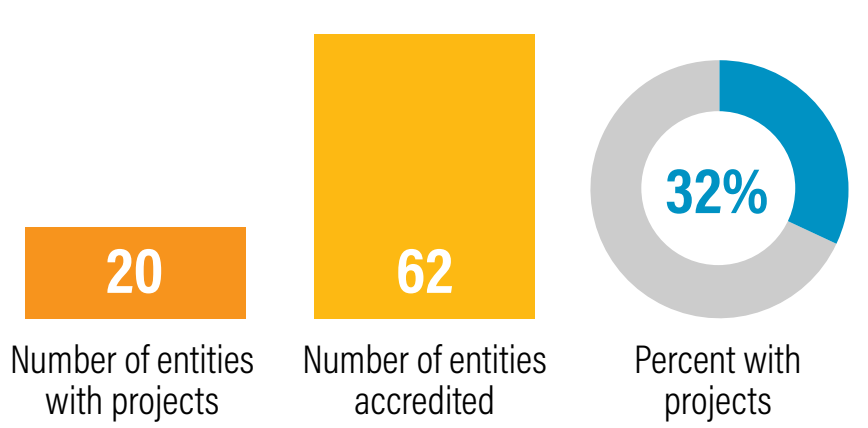

\section{INTERNATIONAL}

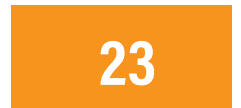

Number of entities with projects

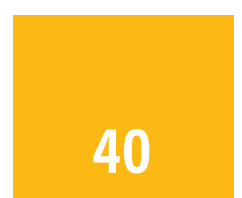

Number of entities accredited

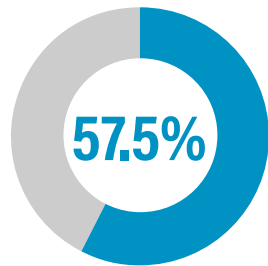

Percent with projects 


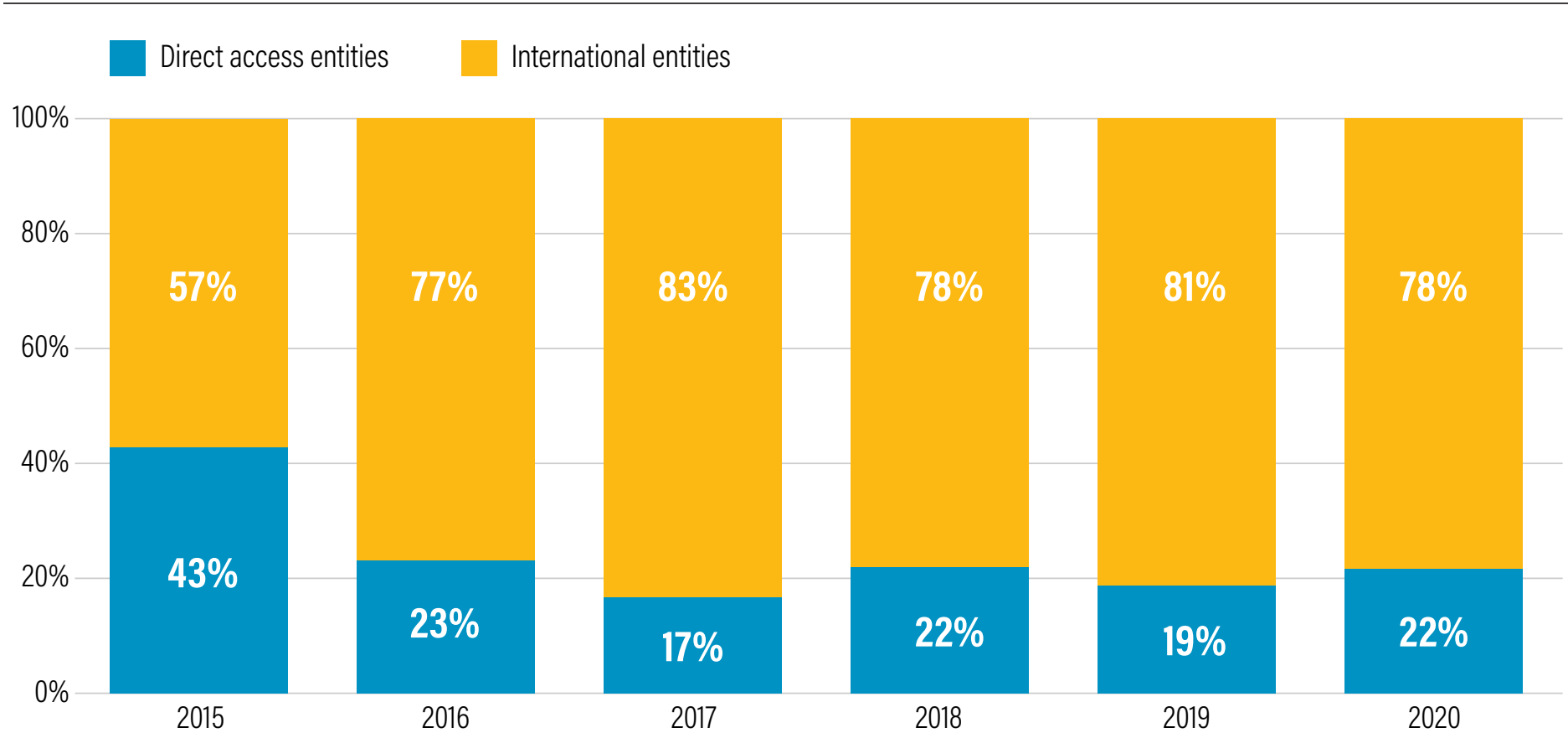

Sources: Green Climate Fund. n.d. "About Us: Partners." Accessed February 1, 2021. https://www.greenclimate.fund/about/partners/ae; Green Climate Fund. n.d. "Projects and Programmes: Project Portfolio." Accessed February 1, 2021. https://www.greenclimate.fund/projects.

Figure 7 | Volume of GCF Finance Portfolio by Direct versus International Entity

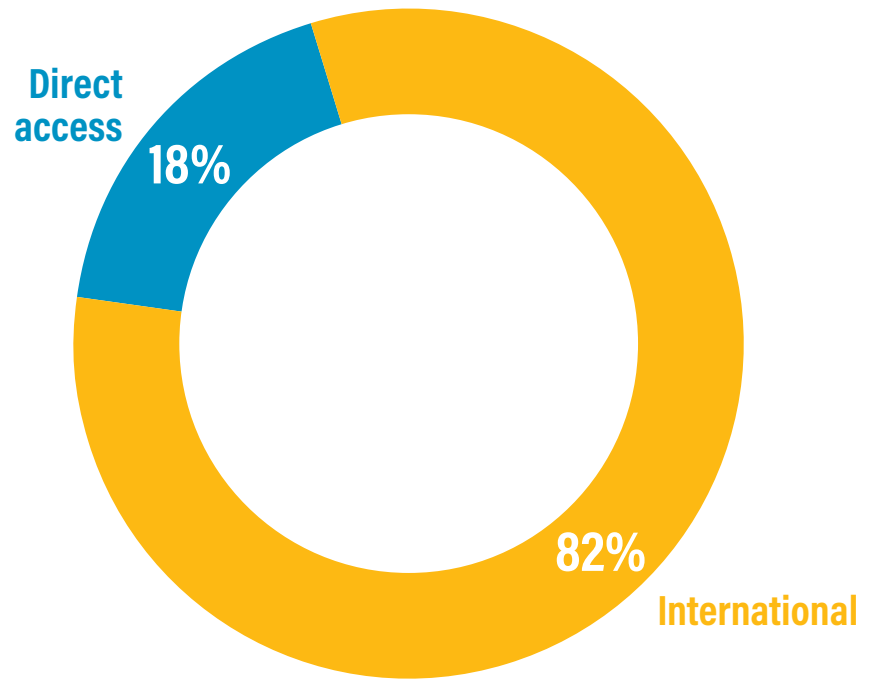

Sources: Green Climate Fund. n.d. "About Us: Partners." Accessed February 1, 2021. https:// www.greenclimate.fund/about/partners/ae; Green Climate Fund. n.d. "Projects and Programmes: Project Portfolio." Accessed February 1, 2021. https://www.greenclimate.fund/ projects.

\section{Support for Direct Access Entities}

The GCF has put in place mechanisms to help ensure that a diverse range of entities can access the Fund's resources. In 2014, its initial year of operation, the GCF created a Readiness Support program to help countries set up systems for accessing the Fund. The following year, it established the Project Preparation Facility to support entities in the development of funding proposals. In 2016, the GCF published a request for proposals for the Enhancing Direct Access modality, which allocated funding for proposals from Direct Access Entities that focused on devolved funding mechanisms. Then, in 2017, the Simplified Approval Process was created to help enable small, low-risk projects to move more quickly through the approval process. 
3. SUCCESSES AND CHALLENGES IN GCF SUPPORT TO ENTITIES SEEKING ACCESS TO THE FUND

Given the central role of direct access to the success of the GCF, the Fund has put in place mechanisms to support Direct Access Entities in their efforts to access GCF finance. Based on our analysis, these mechanisms have room for improvement.

\subsection{Readiness Support}

\section{Key Takeaways}

Both Accredited Entities and those seeking accreditation to the GCF can receive readiness funding to prepare them for engaging with the GCF and developing climate projects.

- Readiness funding is allocated by National Designated Authorities and does not adequately fulfill the needs of Direct Access Entities, especially for project identification and concept note development. ${ }^{1}$

- Readiness support cannot cover the staff time of Direct Access Entities. Such support is critical if Direct Access Entities are to engage effectively and efficiently with the GCF.

The readiness support program was created in 2014 to help countries put in place the systems required to effectively access GCF funding. Readiness funding is meant to provide National Designated Authorities and sometimes Direct Access Entities with financial resources to enable countries to access and manage GCF funds.
Each country can access up to $\$ 1$ million per year in funding to build institutional capacity to access GCF finance and up to an additional $\$ 3$ million for the formulation of national adaptation plans and/or other adaptation planning processes. Funding for readiness projects is requested by the National Designated Authority while implementation can be managed by either the Delivery Partner or the National Designated Authority itself, which is responsible for managing the funding and overseeing activity implementation.

The GCF's current strategy for readiness funding (which covers years 2020-21) allows countries to request funds for multiyear readiness projects of \$1-3 million (see Table 3). The specific activities that can be financed with readiness funds have changed over time. For example, initial readiness funding helped countries establish their National Designated Authorities-but since these authorities are now in place, funding priorities are shifting. Readiness support also previously funded some project development activities that now fall under the mandate of the Project Preparation Facility, although readiness is still used to fund some aspects of concept note development.

The readiness budget for 2020-21 will be $\$ 224.23$ million, a nearly 70 percent increase in the overall size of readiness funding compared with the average from 2014 to 2020.

The GCF reports that, in total, 75 grants have included activities related to Direct Access Entities, primarily to support accreditation. This includes 42 plans for accreditation gap assessments and capacity building. Of the 62 accredited Direct Access Entities, 40 percent have received some type of readiness support from the GCF. Of the 20 Direct Access Entities with approved projects, 55 percent have received readiness support in some form (see Figure 8).

Table 3 | Categories of Readiness Funding and Associated Allocation of Funds for 2019-2021

NEW CATEGORY

Capacity building for climate finance coordination

Strategic frameworks for low-emission investment

Strengthened adaptation planning

Paradigm-shifting pipeline development

Knowledge sharing and learning
ALLOCATION OF GCF READINESS FUND

$10 \%$

$20 \%$

$50 \%$

$15 \%$

$5 \%$

Source: GCF $2020 f$. 
50
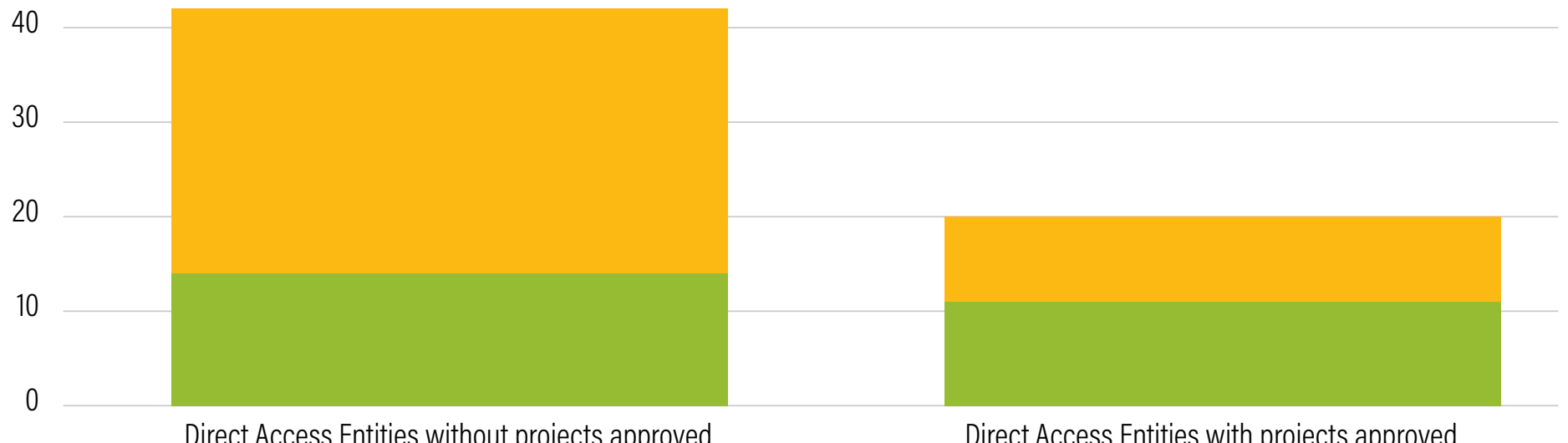

Direct Access Entities without projects approved

Direct Access Entities with projects approved

Note: GCF stands for Green Climate Fund.

Source: Authors' analysis of readiness project documents available at Green Climate Fund. n.d. "Projects and Programmes: Country Readiness." Accessed January 15, 2021. https://www.greenclimate. fund/readiness/documents.

Thirteen of the 62 accredited Direct Access Entities have used readiness support to identify and develop project ideas. For example, readiness funds enabled the South African National Biodiversity Institute to hire consultants to assist with the creation of two projects. The Antigua and Barbuda Ministry of Health and the Environment is using readiness funding to, among other things, conduct feasibility studies on potential project ideas. Similarly, Unidad para el Cambio Rural in Argentina is using the funds to enlist sectoral specialists in agriculture, forestry, GHG inventories, energy, and ecosystems.

However, much of this support related to project development came in the earlier years of the GCF (see Figure 9). For example, nearly all readiness proposals for Direct Access Entities for concept note development were approved prior to 2018 (the one exception to this is the readiness proposal from Protected Areas Conservation Trust approved in October 2019.) $)^{2}$
Figure 9 | Number of Readiness Projects That Have Supported Project Identification or Concept Note Development Specifically for Accredited Direct Access Entities

Project identification Concept note development

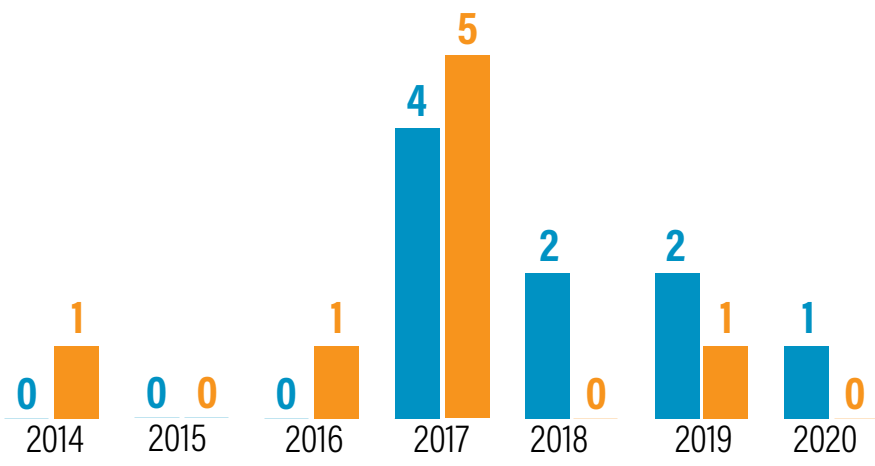

Source: Authors' analysis of readiness project documents available at Green Climate Fund. n.d. "Projects and Programmes: Country Readiness." Accessed January 15, 2021. https://www. greenclimate.fund/readiness/documents. 
Some National Designated Authorities have also used their readiness support funding to strengthen their project selection processes. National Designated Authorities are responsible for developing country programs, which in some cases has led to broad stakeholder consultation on the identification and selection of potential projects. In Bangladesh, for example, the National Designated Authority, while developing the country program, reviewed over 230 project ideas that had been submitted. These ideas were received following 40 meetings and six workshops with stakeholders from across the public and private sectors. The projects were then narrowed to 48 , and an assessment was made to estimate how much funding would come from the GCF versus co-financing from domestic or other international sources. In the country program they also identified several readiness proposals, including two aimed at enhancing the ability of two already accredited national institutions (Palli KarmaSahayak Foundation and Infrastructure Development Company Limited) to identify projects, and another readiness proposal for the accreditation of Bangladesh Bank.

Fifteen of the 62 Direct Access Entities have also worked as Delivery Partners to provide readiness support to National Designated Authorities or other Direct Access Entities. This list of readiness providers includes entities that have achieved project approval and those that have not accessed funding themselves. The entities that have provided readiness are a heterogenous group, with entities ranging from national environment funds accredited for micro projects, such as the Peruvian Trust Fund for National Parks and Protected Areas, to larger regional development banks, such as the Development Bank of Southern Africa.

\section{Readiness Not Living Up to Needs}

Direct Access Entities that have received readiness funding report that it is beneficial. However, the program is not yet optimally designed to help Direct Access Entities access finance due to six constraints:

\section{Focus on National Designated Authorities over Direct Access Entities}

First, readiness is designed primarily with National Designated Authorities in mind as they are the ones that submit all applications for readiness support within a country. While this helps these authorities more effectively guide the countries' engagement with the GCF, it means the focus of support is not on the entities accredited to receive funding. Since National Designated Authorities are the main focus of readiness funding, they are responsible for submitting requests for readiness support. While they can choose to include support for Accredited Entities (or those seeking accreditation), many have not done so. In total, around 23 NDAs have requested some form of support for Direct Access Entities. This support was used for a variety of activities including finalizing accreditation requirements and developing entity work programs, in which Direct Access Entities lay out high-level plans for project ideas that they aim to bring to the GCF.

\section{Lack of support for concept notes}

Second, the focus of support is not on the Direct Access Entities that are looking to develop project proposals. The Project Preparation Facility is meant to focus on developing project proposals once a concept note has been endorsed by the Secretariat. This still leaves a gap for entities as they try to develop concept notes and build a project pipeline. The readiness program offers support for these activities so long as the NDA requests them, but this has created a bottleneck with some entities struggling to get concept notes endorsed and ready for PPF funding.

\section{Long timelines}

Third, Direct Access Entities report that obtaining readiness funds can be very time consuming. These applications must indicate a theory of change, risk management analysis, procurement plan, and monitoring and evaluation plan, among other information. Information requirements have gotten more complex with the addition of line-item and activity-level budgeting, detailed theories of change, and more stringent risk analyses. It is common for entities to submit several versions of the application to the Secretariat before it is approved. As a result, it has taken some entities more than a year to access readiness funds, although the process for approving readiness funding has gradually been getting quicker as the Secretariat has improved its review processes. This may be in part attributed to the Secretariat's hiring of the United Nations Office for Project Services to provide grant management support on its behalf beginning in March 2018 (GCF 2020i).

\section{Restrictions on funding for Direct Access Entity staff}

Fourth, the impact of readiness funding is limited by restrictions on what the funding can be used for. Readiness funds cannot be used for "core support," which means the funds cannot support staff within the Direct Access Entity or National Designated Authority. Funding can go only to hiring consultants and similar external 
costs. This can cause delays because, without resources to cover staff time spent on GCF-related initiatives, the staff at Direct Access Entities must often conduct tasks associated with identifying and developing GCF projects on top of their regular workloads.

The emphasis on using external consultants has also at times reduced the quality of readiness support. Consultants with experience developing successful projects for the GCF can be difficult to find. Consultants can also be unfamiliar with the context within which Accredited Entities work. Centre de Suivi Ecologique (CSE) in Senegal, for example, reports having to redo the work of consultants who were not as familiar with the GCF as CSE's own staff. In addition, international consultants charge higher rates than local consultants, creating a cost inefficiency.

\section{Limits on covering Delivery Partner costs}

Fifth, the relatively low percentage of funds that readiness Delivery Partners can use to cover their own costs acts as a disincentive for those seeking to provide readiness support. Delivery Partners can retain up to 7.5 percent of the total budget and contingency for project management costs (oversight, supervision, management) for all readiness projects under $\$ 3$ million (GCF 2018). Delivery Partners can also act as Executing Entities (which are responsible for implementing approved projects) whereby their costs are covered within the budget, though they must "clearly differentiate" these tasks from those of oversight, which can be difficult. This means fees often do not cover the true cost of developing, managing, coordinating, and monitoring the implementation of readiness support. This appears to have discouraged some international organizations from providing readiness support. It also means that entities like Fundación Avina in Panama, Caribbean Development Bank in Barbados, and CSE, which have acted as readiness providers to their peers, have had to use their own limited resources to make up the difference between what they can receive from GCF funds and the true cost of providing readiness support.

\section{Little flexibility causes delays}

Finally, a lack of flexibility undermines the efficiency with which activities can be implemented. Any "substantial" changes in timelines and activities during readiness implementation must be approved by the GCF, which, given the burden already placed on the Secretariat, can cause further delays to implementation. Fundación Avina, for example, found that by the time the readiness funding was approved, changes had often taken place within the relevant countries where they operate. In one case, some deliverables had already been completed by the government and other development partners by the time the GCF readiness proposal was approved.

\subsection{Project Preparation Facility}

\section{Key Takeaways}

The GCF offers specific funding or support for the development of proposals that meet Fund criteria. This funding can cover impact assessments, feasibility studies, budget development, and other activities based on project needs.

To date, funding for the Project Preparation Facility has been accessed largely by entities that have already successfully gotten at least one project approved (or the project was approved shortly after receiving PPF funds for a second initiative).

- A persistent hurdle for entities as they try to develop projects is getting a concept note endorsed by the GCF. This is a requirement they must meet before they can access PPF funds.

Paying for all the aspects of project development-from the human resources, stakeholder convenings, and travel (for example, to GCF headquarters), to data collection and/or the translation of all documents into English-is a significant investment. In total, concept notes alone frequently cost over $\$ 100,000$ to complete while the costs for developing a full proposal can be much higher. Obtaining such funding has been a significant barrier for many in developing successful proposals. Those Direct Access Entities with approved projects have all used some of their own financing to pay for the process, and over half have accessed assistance from other providers of support, such as bilateral donors, to help pay for project development.

Recognizing that readiness support was not designed to cover the full cost of project development, the GCF developed the Project Preparation Facility in 2016. Like other climate funds (see Table 4) the GCF wanted to provide a way to fund preparatory activities related to funding proposal development. The GCF Board has committed 
\$40 million to the Project Preparation Facility, which provides up to $\$ 1.5$ million per project and can support activities related to developing specific projects such as the following:

Pre-feasibility and feasibility studies

Gender studies and stakeholder analyses

- Studies related to environmental and social risks or other types of risk assessments

- Advisory services for budget development

Development of monitoring and evaluation systems

To apply for funds from the Project Preparation Facility, the Accredited Entity must submit both the PPF application and a no-objection letter from the National Designated Authority (this is in addition to the letter of no objection required at the full proposal stage). As of November 2020, the Project Preparation Facility had approved 37 requests totaling $\$ 23.4$ million, for an average of $\$ 633,000$ per proposal. In total, 12 of the 62 Direct Access Entities have accessed the facility. The facility was designed to primarily support Direct Access Entities with projects under $\$ 50$ million but is open to receiving applications for all project amounts as well as from Inter- national Accredited Entities. To date, almost 32 percent of approved PPF projects have been submitted by International Accredited Entities. The Secretariat does place an emphasis on accepting Project Preparation Facility grants from international entities whose proposed project is either in a country without a Direct Access Entity or whose Direct Access Entity accreditation status does not align with the project. Within two years of approval by the GCF Secretariat of a Project Preparation Facility application, entities must submit a full proposal (GCF 2020e) unless sufficient justification for an extension is provided.

While initially more entities with approved projects received grants from the Project Preparation Facility, more recently several entities without projects have received PPF grants and three Direct Access Entities have used the funds to develop their first projects. For example, the Rwandan Ministry of Environment used a Project Preparation Facility grant to prepare its first successful project proposal, "Strengthening Climate Resilience of Rural Communities in Northern Rwanda” (FPo73), which was approved by the board in March 2018. Since then, the ministry has received three additional grants to develop more proposals.

Table 4 | Project Preparatory Support at Select Multilateral Climate Funds

FUND

Adaptation Fund

Global Environment Facility-Least
Developed Countries Fund, Special
Climate Change Fund

$\$ 200,000$ for proposals up to $\$ 10$ million
$\$ 300,000$ for proposals above $\$ 10$ million

Climate Investment Funds

Green Climate Fund
AMOUNT OF FUNDING FOR PROJECT PREPARATION

$\$ 20,000$ for Project Formulation Assistance Grants

$\$ 50,000-300,000$

$\$ 50,000$ for proposals up to $\$ 2$ million

$\$ 100,000$ for proposals up to $\$ 3$ million

$\$ 150,000$ for proposals up to $\$ 6$ million

Originally a maximum of $\$ 3$ million, though this has shifted and now larger amounts are granted on a case-by-case basis

Maximum of $\$ 1.5$ million

\section{APPROVAL PROCESS}

Requires only submission of simple funding request

Requires only submission of simple funding request

Requires a separate project preparation application with a list of activities and deliverables

Requires a separate project preparation application along with an endorsed concept note

Sources: Adaptation Fund. n.d. "Readiness Grant Funding." Accessed February 9, 2021. https://www.adaptation-fund.org/apply-funding/grants/; Global Environment Facility. 2019. "GEF7 Project Preparation Grant (PPG) Request." https://www.thegef.org/sites/default/files/documents/09GEF7\%20PPG\%20Request\%206-10-2019.doc; Climate Investment Funds. n.d. "Governance: Key Documents." Accessed February 9, 2021. https://www.climateinvestmentfunds.org/documents?field_related_fund_target_id=All\&field_cif_document_types_tid=233\&field_themes_tid_ selective=All\&combine=\&page=1; GCF 2020e. 
Recently, the Project Preparation Facility has also begun to provide limited technical assistance for up to 15 days (with possibility of extension) to strengthen concept notes. The concept note must already have been developed by the entity itself. This technical assistance comes in the form of a GCF-designated sectoral expert or independent project development firm and has so far been prioritized for concept notes that the Secretariat deems as showing particular promise but are not yet ready for approval. Accredited entities that have received this relatively new form of support-including Fundación Avina and Micronesia Conservation Trust, among others-have not had to go through the full readiness or Project Preparation Facility project approval process to receive this assistance and have instead received it directly from the Secretariat.

In addition, in October 2020 the GCF launched two new streamlined services for accessing Project Preparation Facility funding. The Simplified Project Preparation Facility can be used by entities to request up to $\$ 300,000$, which can cover, among other costs, Accredited Entity fees and project management costs. The Simplified Project Preparation Facility has a simplified implementation arrangement and budget compared with the full application. The Secretariat has also developed the Project Preparation Facility Service in which an AE can choose to outsource the administration of the Project Preparation Facility grant to a consulting firm chosen from a preapproved roster. Both of these new services hold promise for making the Project Preparation Facility overall easier to access and more able to meet entities' needs.

\section{Current Challenges with the Facility}

It is still not easy to access funds from the Project Preparation Facility, for two main reasons:

\section{Concept note requirement without accompanying financial support inhibits access for entities with capacity constraints}

Project Preparation Facility funding is approved only after the applicant presents a concept note that is endorsed by the Secretariat. Concept notes require entities to spell out, among other things, the barriers to climate action that the project will address, planned activities for the project, an indicative budget for these activities, how the project aligns with national policies, and risks to project success. While the Project Preparation Facility application itself is only four pages, concept notes can be quite long. They measure 45 pages on average, with the longest reaching
110 pages. Since facility grants can be used only for turning approved concept notes into full funding proposals, the GCF's system of support has a sizeable gap for concept note completion. This gap creates a significant stumbling block for many entities that need basic concept note and project preparation support.

Some Direct Access Entities with access to other sources of funding, including the Brazilian Development Bank and Micronesia Conservation Trust, have opted to use these other funds to develop proposals so that they can avoid delays associated with accessing the Project Preparation Facility. This also allows their own staff to gain experience with GCF procedures. Many others, though, lack access to the financial resources necessary to successfully identify an appropriate project, develop it into a concept note that meets the GCF's requirements, and then submit a successful Project Preparation Facility application.

Perhaps due to the capacity needed to access Project Preparation Facility resources, 68 percent of the grants -24 of the 35 Project Preparation Facility grants approved as of November 2020-have gone to direct and international entities that have already had other projects approved. The 24 Project Preparation Facility grants for Direct Access Entities went to 12 entities. This includes four entities that had already had projects approved, two entities that subsequently had different projects approved without a PPF grant, three entities that had used the facility to get their first project approved, and three others that still do not have a project approved. Half of Direct Access Entities that accessed the facility already had an established track record when seeking Project Preparation Facility funds, and the other half have used the facility to develop their first projects.

\section{Long timelines}

For the 11 Project Preparation Facility grants where data are available, the average length of time from submitting an initial draft PPF proposal to receiving Secretariat approval is one year (counting from the date of submission noted on the PPF application), with the shortest duration being 3 months and the longest 15 months. This is after obtaining endorsement of a concept note, which in and of itself can take many months. Concept notes are reviewed by several GCF departments before endorsement (see Figure 10). This includes the origination and structuring team, made up of experts from several divisions and led by someone from either the Division of Mitigation and Adaptation or the Private Sector Facility. 
Figure 10 | Review Process for Green Climate Fund Proposals

\section{PROJECT ORIGINATION}

WHAT:

Submission of a first concept note or funding proposal
SECRETARIAT LEAD:

Division of Mitigation and Adaptation or Private Sector Facility

\section{SECRETARIAT REVIEWERS:}

Division of Mitigation and Adaptation or Private Sector Facility

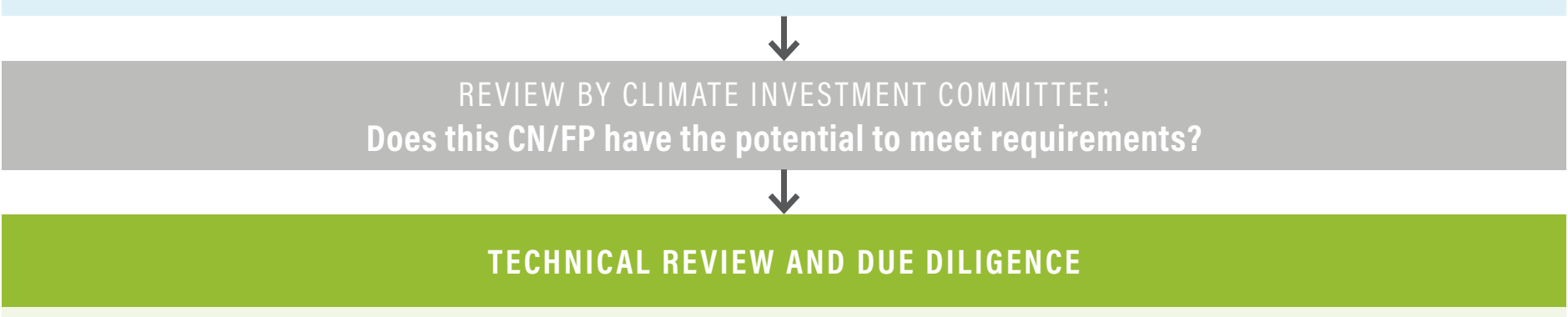

WHAT:

Second-level development, engagement, and due diligence
SECRETARIAT LEAD:

Division of Mitigation and Adaptation, Private Sector Facility, Office of Risk Management
SECRETARIAT REVIEWERS:

- Private Sector Facility specialist

- Division of Mitigation and Adaptation specialist

- Office of Portfolio Management

- Division of Country Programming

- Office of Risk Management and Compliance

- Office of the General Counsel

- ESS \& Gender

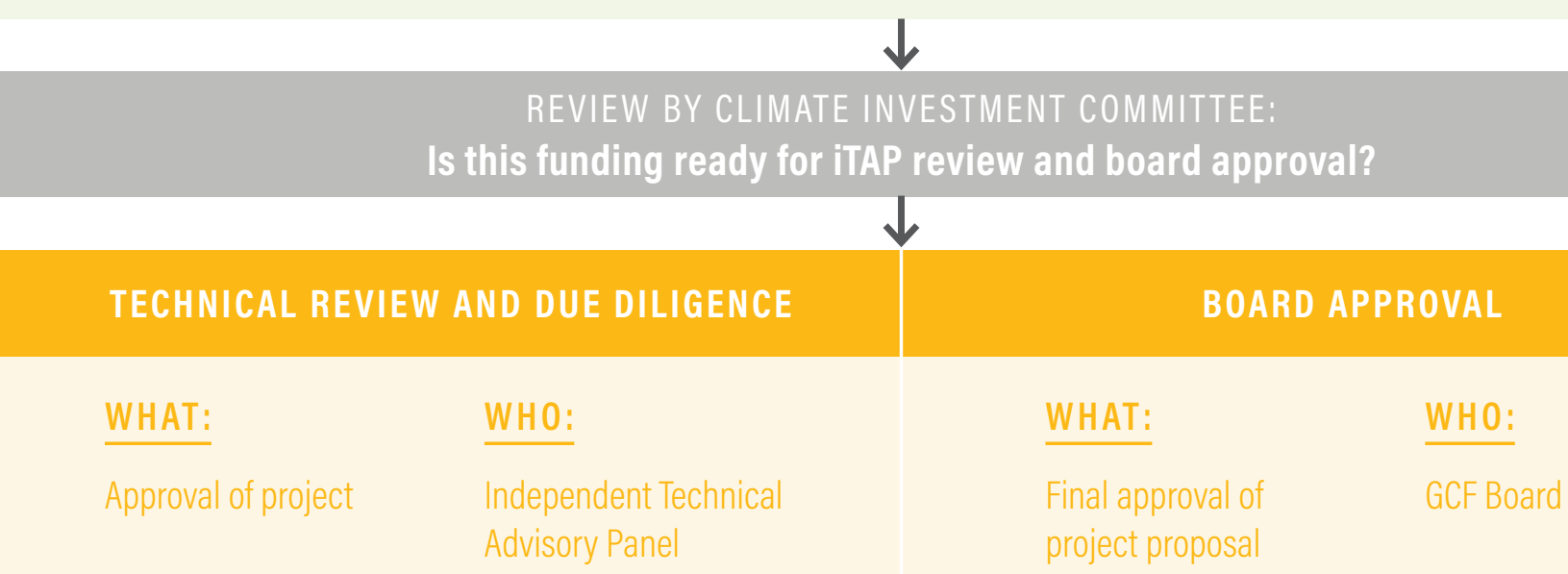

Note: Abbreviations: CN: concept note; FP: full proposal; GCF: Green Climate Fund; ESS: environmental and social safeguards; iTAP: independent Technical Advisory Panel. Source: GCF 2020c. 


\subsection{Simplified Approval Process}

\section{Key Takeaways}

The Simplified Approval Process was developed to shorten the project approval process for small and low-risk projects.

This process has not proved to be significantly simpler than that for larger or higher-risk projects.

In September 2017, the GCF Secretariat, on directions from the board, launched a pilot scheme for a Simplified Approval Process. This pilot was developed in recognition of the barriers that Accredited Entities were facing in getting projects approved through the full proposal process. The stated objective of the pilot program was to "apply best practice in order to reduce the time and effort needed in the preparation, review, approval and disbursement procedures of small-scale projects and programmes" (GCF 2017).

The Simplified Approval Process can be used for projects no greater than $\$ 50$ million with a GCF contribution of $\$ 10$ million or less and that carry environmental and social risks that are mild, minimal, or nonexistent (Category C) (GCF 2017). This means this process can be used for all micro and small projects where the GCF's contribution does not exceed $\$ 10$ million. The Simplified Approval Process has sought for 50 percent of funding to go to Direct Access Entities. Currently, 6 of the 19 projects (31.5 percent) approved under the SAP are from Direct Access Entities. Simplified Approval Process projects have focused mainly on adaptation (12) or cross-cutting (4) themes, with only 3 of the 19 projects focused on mitigation.

\section{The GCF Simplified Approval Process Is Not Really Simpler}

Despite its name, the Simplified Approval Process has, to date, not provided a genuinely simplified process for project approval, for three main reasons:

\section{Similar steps in the review process for regular and streamlined proposals}

In terms of the review process, the Secretariat has implemented certain steps to speed up procedures for Simplified Approval Process projects, including using a separate online submission system. However, the main steps of the review process remain the same as for full proposals and the approval process is not markedly shorter. In its initial assessment of the Simplified Approval Process, published in March 2020, the GCF's Independent Evaluation Unit (IEU) found that the simplified processing times were 8 percent shorter, on average, than a comparable set of full proposals (see Figures 11 and 12). The median number of days from concept note submission to approval is 34 days shorter through the Simplified Approval Process-an average of 365 days for the SAP compared with 399 for other projects. When compared with full proposals for projects with low environmental and social risk, the differences in processing time disappears, indicating that reduced requirements for low-risk projects may be playing a larger role than the Simplified Approval Process in slightly reducing the review time (Gonzales et al. 2020).

The Secretariat has suggested measures to speed up the review process, including approving projects between board meetings, but as of writing (January 2021) these have not been approved by the board (GCF 2020g).

\section{Figure 11 | Size of Proposals versus Financing by Type of Accredited Entity}

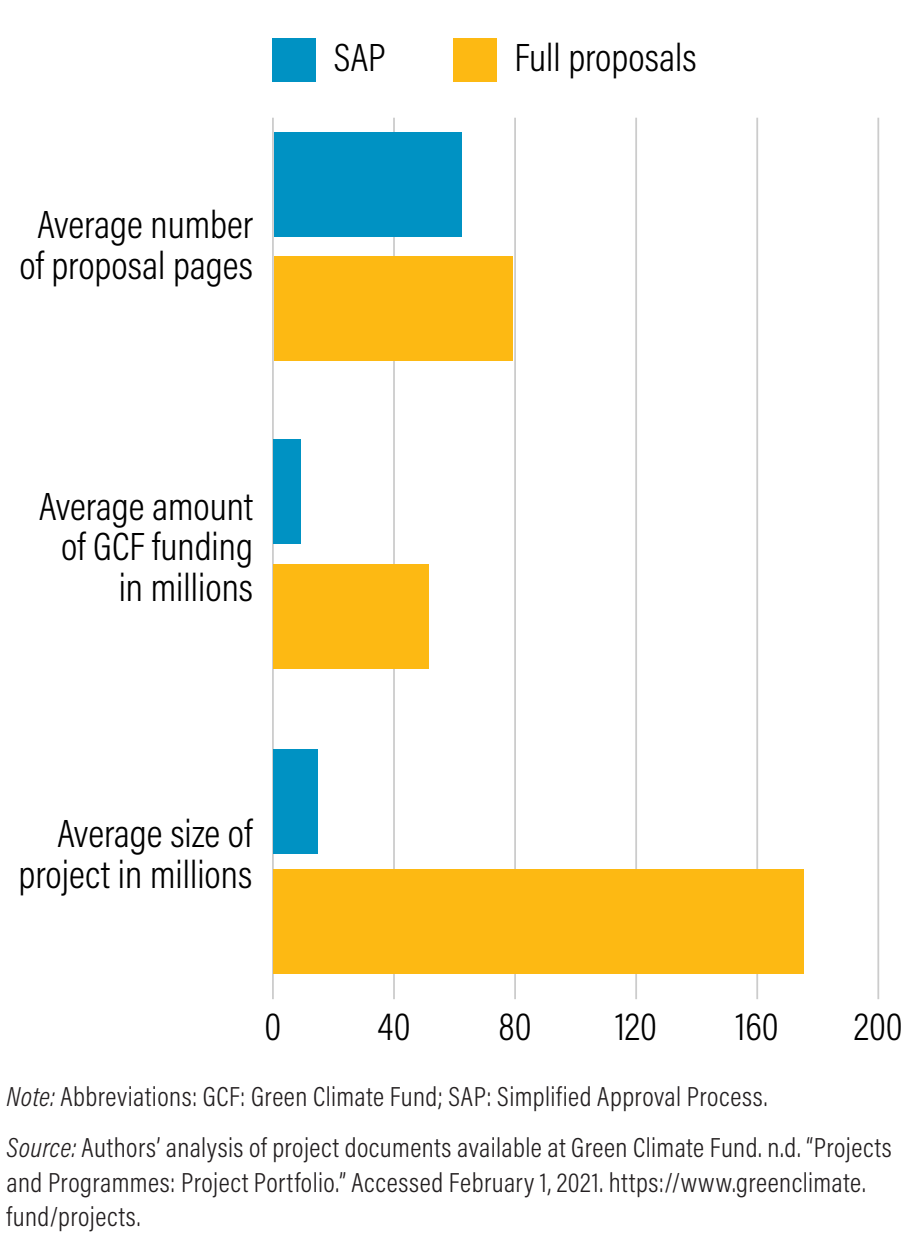


Figure 12 | Days Spent in Each Stage of the Approval Processes

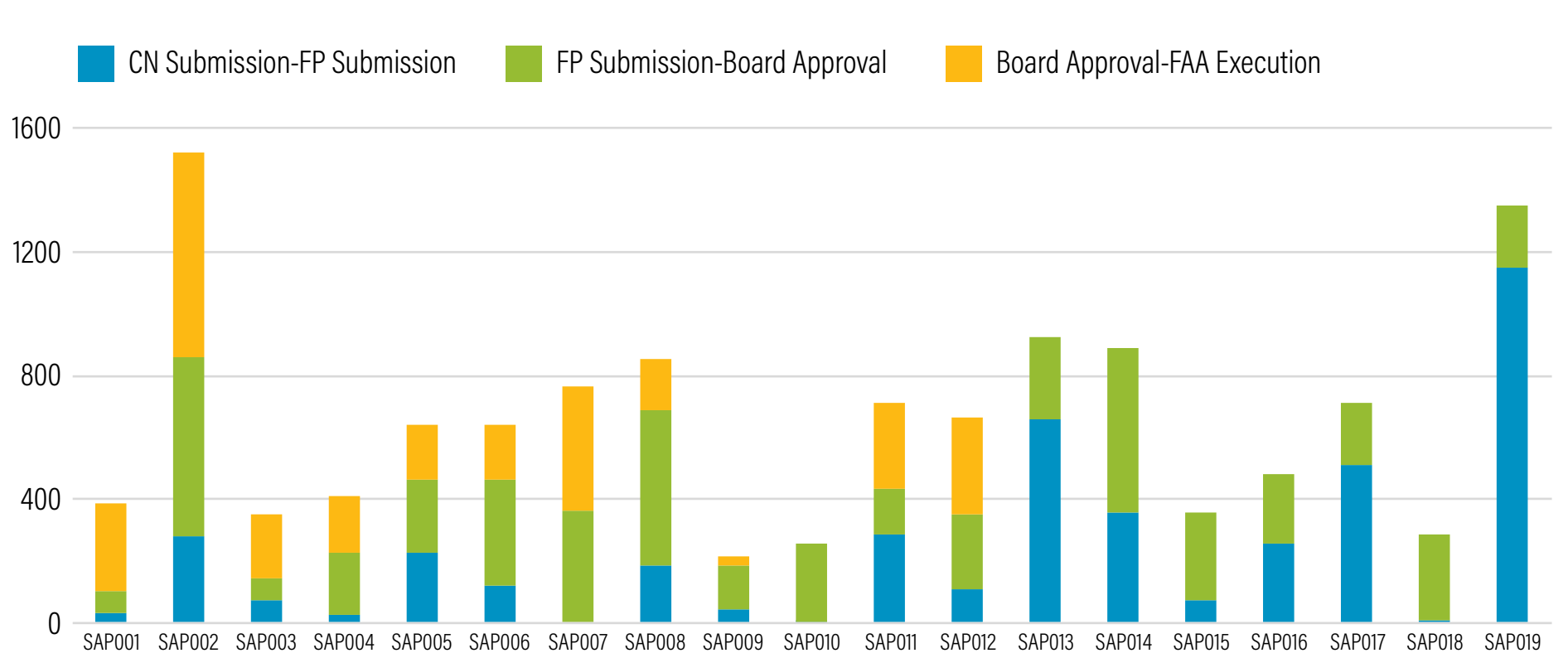

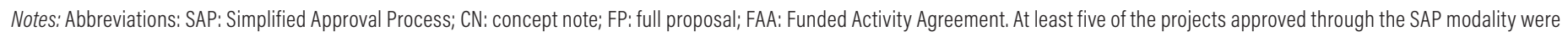
submitted by entities whose Accreditation Master Agreement had not been executed at the time of approval, which also added to the FAA execution timeline.

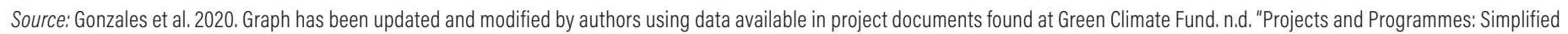
Approval Process." Accessed February 10, 2021. https://www.greenclimate.fund/projects/sap.

\section{Similar proposal requirements for regular and streamlined proposals}

One reason the Simplified Approval Process is not much quicker is that these proposals have very similar requirements to those for larger or riskier projects. For example, both the Simplified Approval Process and full proposal templates ask for the paradigm shift potential, impact potential, relationship to sustainable development, and the needs of the recipients. The biggest difference between the two proposal templates is the number of words required for each answer. However, during proposal review, entities are asked for further documentation, which means that information requirements are essentially the same in the end.

In its review, the IEU noted: "Although it is meant to be a simplified approval process, proposals accessing the simplified approval process modality have similar requirements in terms of initial due diligence. This belies the aim of the process" (IEU 2020). This report also notes that the cost of drafting an SAP proposal averaged between $\$ 100,000$ and $\$ 150,000$, and was as high as $\$ 400$,ooo. Changes to the Simplified Approval Process information requirements have not been proposed as of writing.

\section{Simplified Approval Process proposals are long and getting longer}

The most recent template for the Simplified Approval Process states that full proposals should "not exceed 20 pages.” Nevertheless, the 19 approved SAP proposals averaged 62 pages, excluding annexes (see Figure 11). To respond to comments from the independent Technical Advisory Panel (iTAP) - the GCF's independent review body-or the Secretariat, Accredited Entities regularly end up submitting 10 times the number of words indicated in the template. This results in the GCF's page number guidance being unhelpful and unreliable.

The Simplified Approval Process template includes several questions that are arguably duplicative. For example, entities are asked to answer separate questions for "scalability and the potential for transformation," "paradigm shift objectives," and "paradigm shift potential." This is in addition to other questions about the outline of the project, project details, and a detailed logical framework. While the questions mirror various requirements, including the investment framework, put forward by the board, they do not lend themselves to a simple and efficient proposal template. 
In addition, the Simplified Approval Process template has gotten only more complex over time, in parallel with the full proposal template. In 2018, for the first Simplified Approval Process project put forward by the Environmental Investment Fund (EIF) in Namibia, there were 10 annexes required only if applicable. EIF submitted 4 out of the 10. For an SAP project approved in April 2020 by the Nordic Environment Finance Corporation (NEFCO), there were 9 mandatory annexes along with an additional 11 annexes that were required only if applicable or requested. Of these 21 potential annexes, NEFCO submitted 20.

\subsection{Enhancing Direct Access Pilot}

\section{Key Takeaways}

The Enhancing Direct Access pilot had a target of approving 10 proposals over a five-year period but only two projects ended up achieving approval.

The limited funding pool for Enhancing Direct Access pilot projects, coupled with additional proposal requirements and an unclear distinction between pilot projects and regular GCF proposals, may be limiting the success of the Enhancing Direct Access pilot.

Early in the GCF's creation, board members from developing countries (and some developed countries) advocated for a form of direct access that delegated even greater responsibility to institutions in the recipient country. As a result, the Governing Instrument of the GCF states that the board "will consider additional modalities that further enhance direct access" (GCF 2011). One way in which board members sought to follow through on this commit- ment was through the creation of an Enhancing Direct Access pilot program. Approved in 2015, the program is a way for the Fund to partner with National Designated Authorities and Direct Access Entities to develop projects, such as small grants programs and microfinance initiatives, where decisions over what exactly is to be funded are taken nationally, with "increased national oversight and multi-stakeholder engagement at the country level" (GCF 2016).

The Enhancing Direct Access pilot was meant to run for five years and provide up to $\$ 200$ million for at least 10 pilots, including at least 4 pilots to be implemented in Small Island Developing States (SIDS), least developed countries (LDCs), and African states. Projects under the Enhancing Direct Access pilot could focus on adaptation or mitigation and could be put forward by both public and private Direct Access Entities.

The Enhancing Direct Access pilot has not met its goals according to the original timeline. In the five years since the pilot was approved, only two pilot projects have been approved, using \$30 million of the original \$200 million. These projects are from the Ministry of Health and Environment in Antigua and Barbuda and the Environmental Investment Fund in Namibia. While there are still 14 projects in the Enhancing Direct Access pilot pipeline, the GCF did not receive nearly the same number of submissions for this opportunity as other GCF requests for proposals, which generated requests five or six times the size of their original allocation and have had more projects approved in shorter time frames (see Table 5).

Table 5 | GCF Request for Proposal Status

\begin{tabular}{|c|c|c|c|c|}
\hline PILOT & APPROVED & ALLOCATION & $\begin{array}{l}\text { TOTAL FUNDING } \\
\text { REQUESTS }\end{array}$ & COMMITTED FUNDING \\
\hline Enhancing Direct Access & July 2015 & $\begin{array}{l}\$ 200 \text { million for } 10 \\
\text { projects }\end{array}$ & \$284 million & $\$ 30$ million, two projects \\
\hline $\begin{array}{l}\text { Micro, small, and medium-sized } \\
\text { enterprises }\end{array}$ & July 2015 & $\$ 100$ million & $\$ 739$ million & $\begin{array}{l}\$ 60 \text { million, three } \\
\text { projects }\end{array}$ \\
\hline Mobilizing Funds at Scale & July 2015 & $\$ 500$ million & $\$ 18$ billion & $\begin{array}{l}\$ 95 \text { million, three } \\
\text { projects }\end{array}$ \\
\hline REDD+ & October 2017 & $\$ 500$ million & $\mathrm{N} / \mathrm{A}$ & $\$ 361$ million, six projects \\
\hline
\end{tabular}

Sources: GCF 2019a, 2019b. 


\section{The Current Limits on the Enhancing Direct Access Pilot May Be Undermining Its Success}

There are likely multiple factors that have so far limited the success of the Enhancing Direct Access pilot:

\section{Additional operations and governance requirements to access funds}

One factor is the difficulty associated with accessing the funds. While Direct Access Entities continue to emphasize their support for Enhancing Direct Access, they also note that accessing the program can be difficult in its current form. In addition to the regular project approval requirements, Enhancing Direct Access pilot programs should create either an operations manual indicating how the entity will make funding decisions or otherwise indicate how governance arrangements will work. Proposals are meant to include information on risk mitigation systems, monitoring and evaluation processes, and a pipeline of sub-projects that have been identified, including detailed descriptions of a few examples of such sub-projects (e.g., objectives, financial structure, alignment with GCF investment criteria and results areas, implementation arrangement). Entities are also strongly encouraged to find longterm financing for the proposed financing facilities.

To show how the project will be governed, entities are also required to set up a decision-making body that includes members of civil society and the private sector, and other relevant stakeholders, along with an oversight body (see Figure 13 for an example provided by the GCF). While such inclusive decision-making can beneficially support widespread ownership over the funding mechanism, setting up and running complex multi-stakeholder bodies can be a challenge for entities that do not normally operate through such governance structures, including private sector institutions. In January 2021, the GCF released further guidelines on how these projects should be developed.

Figure 13 | Sample Governance Structure for an Enhancing Direct Access Pilot Provided by the GCF

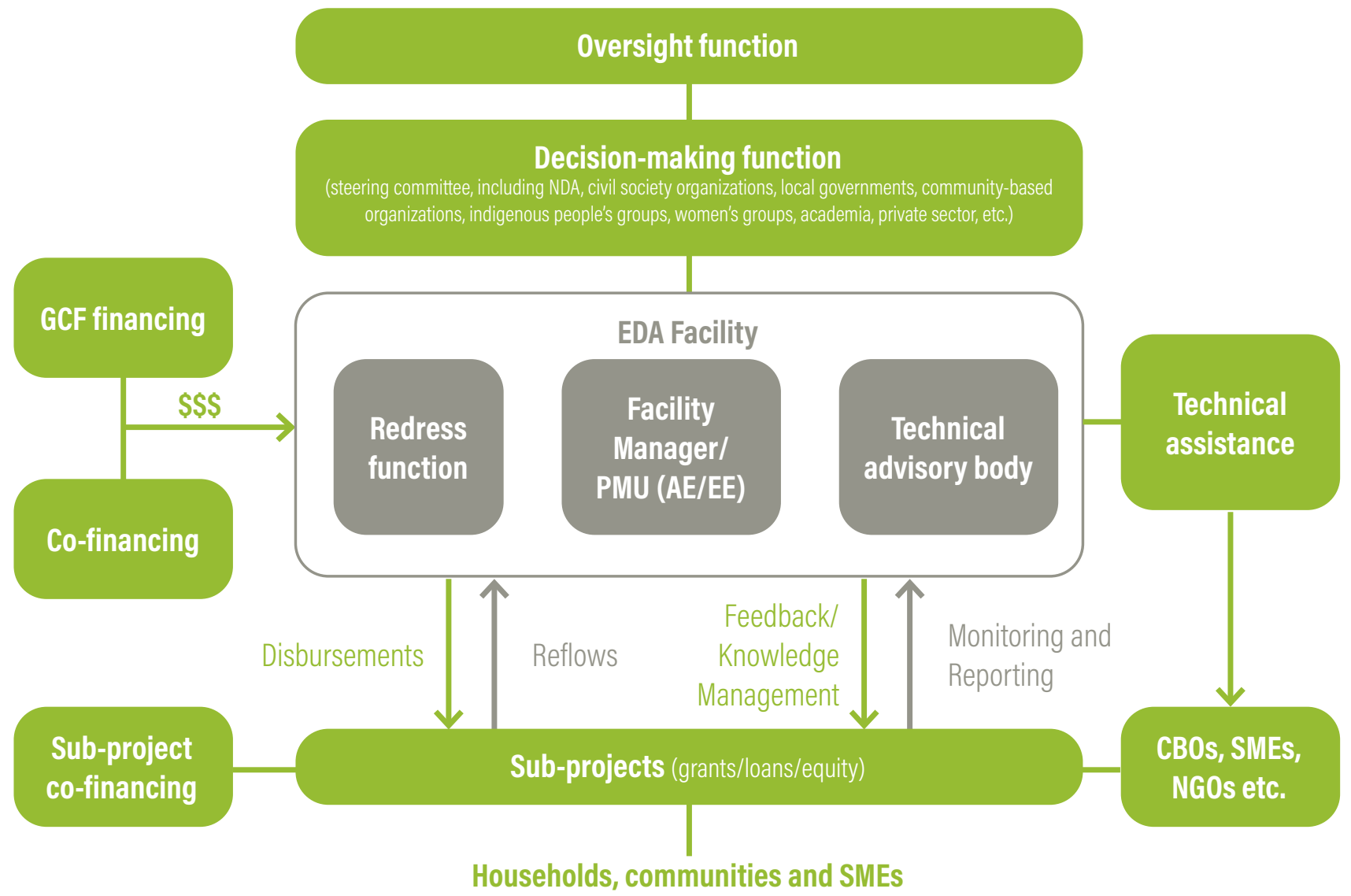

Notes: Abbreviations: GCF: Green Climate Fund; CBO: community-based organization; EDA: Enhancing Direct Access; NDA: National Designated Authority; NGO: nongovernmental organization; SME: small or medium-sized enterprise; PMU: project management unit; AE: Accredited Entity; EE: Executing Entity. 


\section{Lack of clarity around activities that qualify for funding}

Prior to the release of these guidelines, entities also experienced a lack of clarity as to what pilot funding may cover. In its original Enhancing Direct Access proposal, "Empower to Adapt" project (FPo24), EIF proposed an extensive program to build awareness and capacity around integrating climate considerations into planning and establishing local climate change monitoring systems at the community level. This element of the project was to be implemented through local Executing Entities. However, the GCF board removed most of the activities in this component and cut the budget from $\$ 893,500$ to $\$ 272,000$ based on a recommendation from iTAP, which thought the component was not sufficiently connected to climate change and not properly designed. Now that the project is under implementation, the lack of a strong capacitybuilding component and the more limited engagement of local entities is complicating project implementation. In a subsequent project proposal, EIF again included support for capacity building. This time it was accepted by iTAP and the board.

\section{Funding size and type may be limiting interest}

The funding cap of $\$ 200$ million for 10 projects may be limiting the number of entities for which this request for proposals presents a compelling opportunity. While there is no hard funding cap for each individual Enhancing Direct Access pilot project, the availability of $\$ 200$ million for 10 projects implies that each project should not be much larger than $\$ 20$ million. Over 70 percent of Direct Access Entities are accredited to receive larger amounts of funding than this from the GCF. Of the 13 private Direct Access Entities, only 4 are accredited for micro (1) or small (3) projects.

Entities must be accredited for grant award and/or onlending to be approved for an Enhancing Direct Access pilot project due to the nature of devolved decisionmaking required in these projects. While 52 Direct Access Entities (84 percent) have at least one of these accreditation types, 10 entities do not. Of these 10, all but 1 is accredited for small and micro projects. It is possible that the accreditation requirement, combined with the funding level, is limiting the number of entities for which the pilot program presents a viable and attractive funding option.

\section{Advantages over regular project approval process are unclear}

The benefit of taking the Enhancing Direct Access route as it is structured today is not always clear. There have been several projects approved within the GCF portfolio that reflect a similar devolved funding structure as Enhancing Direct Access pilots are meant to support. For example, in Guatemala, the International Union for Conservation of Nature's project (FP087) has set aside $\$ 15$ million for a grant facility for community-led climate action in Guatemala's Highlands. Meanwhile, Acumen's KawiSafi Ventures project in Kenya and Rwanda made \$2-10 million investments in 10-15 small and medium-sized enterprises.

\section{RECOMMENDATIONS}

This section provides recommendations for how to better support Direct Access Entities in obtaining project approval.

\subsection{Reform Readiness Support and the Project Preparation Facility}

The GCF should implement the following steps to improve access to financial support for project identification and development.

\section{Simplify and Automate Access to Preparatory Funding}

If direct access is to succeed, Direct Access Entities need financial and technical support to be able to meet the GCF's unique requirements. There are several steps the GCF could take to ensure that it can effectively and efficiently provide financial support that enables entities to submit successful project proposals.

\section{One big step would be to move away from mak- ing a distinction between readiness funding and project preparatory support. Instead of its current, somewhat unclear approach, the GCF should focus its financial and technical support on key steps in the project development process: accreditation, project identification, concept note development, and the development of full proposals (see Figure 14).}




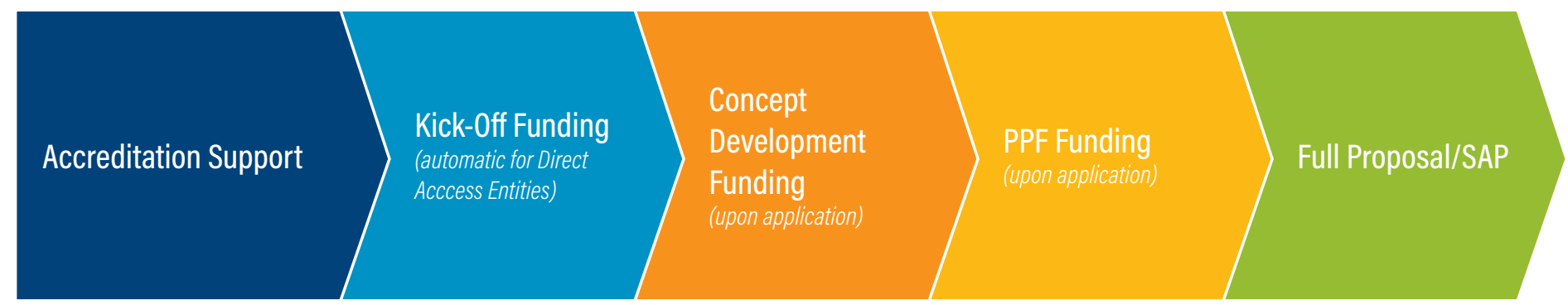

Note: Abbreviations: PPF: Project Preparation Facility; SAP: Simplified Approval Process. Source: Authors.

Under this proposal, as Direct Access Entities move from accreditation to project selection, they would automatically receive "kick-off" funding. This funding would enable entities to conduct an initial assessment of project ideas, initiate outreach, collect relevant project data, and conduct other activities to move forward with project development. The funding would be a preset amount based on the size of project accreditation and be provided automatically upon achieving accreditation to eliminate the long wait between accreditation and the receipt of any GCF funds. Based on our interviews and the GCF's Independent Evaluation Unit's own findings, funding in the range of $\$ 100,000-250,000$ would be a meaningful amount to help entities get started and avoid early hurdles to accessing funding. All Direct Access Entities could receive the same amount, or the rate could change based on the size of the Direct Access Entity and/ or the level of development of the headquarter country (for example, entities from SIDS, LDCs, and African states could receive a higher amount).

Another big step would be to combine the applications for concept note and PPF funds, so that one application would cover both phases of project development. Funding would then be released in tranches-the funding to develop a concept note would be released first, while funding for full proposal development would be released only after the concept note had been completed and approved by the Secretariat. Entities could be granted funding to create concept notes for more than one project idea, thus empowering them to explore different options and choose the most promising one to develop into a full proposal. Funding exclusively for National Designated Authorities to support planning and capacity building, including funding for National Adaptation Planning, could still be available separately.
Finally, to further streamline the process of accessing funds, the GCF could simplify the information required. For example, most readiness requests today that cover support for entities include assistance with environmental and social safeguard policies, gender policies, financial accounting systems, or entity work programs. The GCF could follow the Adaptation Fund's readiness model, where proposals are shorter for requests that fall into common categories, with standardized templates for each These categories include: South-South Cooperation Grants of up to $\$ 50,000$; Project Formulation Assistance Grants of up to \$30,000; Technical Assistance Grants of up to \$25,000; and Project-Scale-Up Grants of up to $\$ 100,000$ (Adaptation Fund n.d.).

\section{Allow Preparatory Funding to Be Used Where It Is Most Needed, Including Staff Time}

The GCF should ensure that the readiness funding Direct Access Entities receive allows them to meet their most pressing financial needs. This means allowing entities to cover some of their own costs associated with the time staff spend on project identification and development. Allowing entities to use preparatory project funds to cover some of these costs in-house could help speed up project development and would facilitate greater staff ownership over the project development process and keep more funding in developing countries' local economies.

\section{Ensure Access to High-Quality Expertise, Including through Peer Exchange}

In addition to financial support, the GCF should continue to ensure that Direct Access Entities have access to highquality expertise, namely to experts who understand the unique requirements of the GCF. 
The GCF should continue to enable access to experts with deep knowledge of the GCF's rules and processes, including Secretariat staff. The Fund can do so by building on the approach it has taken under the PPF to provide internal GCF consultants to entities on a short-term basis to support concept note development. Providing GCF experts to entities on a longer-term basis (at least three months) could be particularly helpful in building on-the-ground expertise. It would not only give smaller, newly accredited entities access to necessary GCF-specific expertise, but also help these experts become more familiar with the organization and its operational context.

The GCF should increase its support for peerto-peer exchange with an emphasis on pairing newly accredited entities with staff at similarly sized organizations that have achieved project approval, ideally from the same region. One source of GCF expertise lies with Accredited Entities that have already succeeded in accessing GCF project funding, including both direct and international entities. Their uniquely relevant experience makes staff at these organizations a key resource for other organizations. Funding should be provided for this peer support-the Adaptation Fund's South-South Cooperation Grants provide one model for how to do this effectively These grants provide \$50,000 to support learning and cooperation between Direct Access Entities and organizations seeking accreditation (Adaptation Fund n.d.).

\subsection{Put the Simple in the Simplified Approval Process}

In terms of the approval process for full projects, the GCF should ensure that the Simplified Approval Process is reformed to reduce the burden on Accredited Entities and the Secretariat. The Fund should do so not just by streamlining the process for approving SAP projects but also by making the proposal requirements for projects less burdensome.

On the process side, the GCF should streamline the Secretariat and iTAP review processes for SAP projects. Recent reviews of both the iTAP and Simplified Approval Process commissioned by the GCF suggest, for example, that SAP proposals should go through a less formal independent review than that currently provided by iTAP (GCF 2020b, 2020c).

In terms of SAP proposal information requirements, where word number or page limits are in place, the Fund should adhere to these requirements and reduce the number of questions in the proposal template. It should do so without risking that the Fund will have insufficient information to make a decision. For example, the Fund could leave out Section E (Expected Performance against Investment Criteria) and instead use the prior questions to understand whether the activities fit within the GCF's requirements, including those in Section D (Logic Framework, Monitoring, Reporting, and Evaluation). The GCF could also waive the pre-feasibility study requirement for Simplified Approval Process proposals.

In addition, once requirements have been further simplified, the GCF should consider increasing the GCF co-financing threshold to include projects with GCF co-financing of up to \$25 million from the current \$10 million cap. This increase would most benefit Direct Access Entities given that around one-third of Direct Access Entities are accredited for small projects.

\subsection{Make the Enhancing Direct Access Modality Easier to Access and More Rewarding}

The GCF should investigate further the current benefits that accrue to Direct Access Entities that implement an Enhancing Direct Access pilot project versus the challenges of doing so. The GCF should not see the lack of projects in the Enhancing Direct Access pilot as an indication of a lack of interest in funding modalities that further devolve decision-making to the national or subnational level. Nor should it be taken as an indication that national institutions are fundamentally unable to implement such devolved decision-making systems.

We suggest that the GCF do the following: eliminate the cap on Enhancing Direct Access pilot funding so that larger projects can be implemented under the modality; and clarify further how Enhancing Direct Access pilot projects differ from normal on-lending or grant-award programs. If the same types of projects with the same degree of decision-making autonomy can be implemented through regular projects as through Enhancing Direct Access, the value of having a separate modality becomes questionable. To ensure that this is not the case, the Enhancing Direct Access modality should provide a noticeable difference in the degree of flexibility provided to funding recipients. 


\section{APPENDIX A. LIST OF STAKEHOLDERS INTERVIEWED}

Interviews were conducted with representatives from the following Direct Access Entities:

\section{COUNTRY}

Antigua and Barbuda

Argentina

Armenia

Bangladesh

Bangladesh

Barbados

Belize

Belize

Benin

Bolivia/Venezuela

Brazil

Chile

Colombia

Colombia

Cook Islands

Ethiopia

Fiji

Ghana

Honduras

India

Indonesia

Kenya

Mexico

Micronesia

Mongolia

Morocco

Morocco

Namibia

Nepal

New Caledonia

Pakistan

\section{ENTITY}

Department of Environment, Ministry of Health and Environment

Unidad para el Cambio Rural

Environmental Project Implementation Unit, State Agency of the Ministry of Nature Protection, Armenia

Infrastructure Development Company Ltd.

Palli Karma-Sahayak Foundation

Caribbean Development Bank

Caribbean Community Climate Change Centre

Protected Areas Conservation Trust

Fonds National pour L'Environnement

Corporación Andina de Fomento

Banco Nacional de Desenvolvimento Economico e Social

Finanzas y Negocios Servicios Financieros Limitada

Financiera de Desarrollo (FINDETER)

Fondo para la Acción Ambiental y la Niñez

Ministry of Finance and Economic Management

Ministry of Finance and Economic Cooperation

Fiji Development Bank

Ecobank Ghana Limited

Central American Bank for Economic Integration

National Bank for Agriculture and Rural Development

PT Sarana Multi Infrastruktur

National Environment Management Authority

Fondo Mexicano para la Conservación de la Naturaleza

Micronesia Conservation Trust

XacBank

Agency for Agricultural Development

Attijariwafa Bank

Environmental Investment Fund

Alternative Energy Promotion Centre

Pacific Community

JS Bank Limited 


\section{COUNTRY}

Panama

Peru

Philippines

Rwanda

Samoa

Senegal

South Africa

South Africa

Tanzania

Tunisia

Uganda

United States

\section{ENTITY}

Fundación Avina

Peruvian Trust Fund for National Parks and Protected Areas

Land Bank of the Philippines

Ministry of Environment

Secretariat of the Pacific Regional Environment Programme

Centre de Suivi Ecologique

Development Bank of Southern Africa

South African National Biodiversity Institute

CRDB Bank PLC

Sahara and Sahel Observatory

Ministry of Water and Environment

Acumen

Interviews were conducted with representatives from the following National Designated Authorities:

\begin{tabular}{|l|l|}
\hline COUNTRY & DEPARTMENT \\
\hline Benin & Ministry of Living Environment and Sustainable Development \\
\hline Brazil & Secretariat for International Affairs, Ministry of Economy \\
\hline Cook Islands & Climate Change Division of the Office of the Prime Minister \\
\hline Fiji & Ministry of Economy \\
\hline Kenya & National Treasury \\
\hline Micronesia & Department of Finance and Administration \\
\hline Mongolia & Ministry of Environment and Tourism \\
\hline Namibia & Ministry of Environment and Tourism \\
\hline Philippines & Climate Change Commission \\
\hline Samoa & Ministry of Finance \\
\hline Uganda & Ministry of Finance, Planning, and Economic Development \\
\hline
\end{tabular}


Interviews were conducted with representatives from the following International Accredited Entities:

- Agence Française de Développement

- Nederlandse Financierings-Maatschappij voor Ontwikkelingslanden N.V.

- European Investment Bank

- United Nations Development Programme

- World Bank

Interviews were conducted with representatives from the following Green Climate Fund Secretariat Departments:

- Division of Private Sector Facility

- Office of the General Counsel

- Office of Risk Management and Compliance

- Division of Country Programming

- Division of Mitigation and Adaptation

- Office of Portfolio Management

\section{GLOSSARY}

\begin{tabular}{ll}
$\begin{array}{l}\text { Accredited } \\
\text { Entities }\end{array}$ & $\begin{array}{l}\text { Institutions that have gained accreditation to the } \\
\text { Green Climate Fund (GCF). Accreditation means } \\
\text { they have met GCF standards, which allows them } \\
\text { to submit projects and receive funding. }\end{array}$ \\
\hline $\begin{array}{l}\text { Direct Access } \\
\text { Entity }\end{array}$ & $\begin{array}{l}\text { Institutions that are accredited to the GCF that are } \\
\text { either subnational, national, or regional and are } \\
\text { based in developing countries. }\end{array}$ \\
\hline $\begin{array}{l}\text { International } \\
\text { Accredited Entity }\end{array}$ & $\begin{array}{l}\text { Institutions that are accredited to the Green } \\
\text { Climate Fund and operate across multiple regions } \\
\text { and countries. }\end{array}$ \\
\hline $\begin{array}{l}\text { National } \\
\text { Designated } \\
\text { Authority }\end{array}$ & $\begin{array}{l}\text { Government institutions that are the interface } \\
\text { between countries and the GCF. They are } \\
\text { responsible for signing a non-objection letter for } \\
\text { all projects that take place in their country and } \\
\text { nominating institutions for accreditation to the } \\
\text { GCF. }\end{array}$ \\
\hline Delivery Partner & $\begin{array}{l}\text { An institution that may or may not be accredited } \\
\text { to the GCF that provides technical assistance to } \\
\text { both National Designated Authorities and entities } \\
\text { that are either seeking accreditation or are } \\
\text { accredited. }\end{array}$
\end{tabular}

Executing Entity Entities that are responsible for implementing approved projects. They receive financing from Accredited Entities or can be an Accredited Entity themselves. 
1. Concept notes include information such as the barriers to climate action that the project will address, planned activities for the project, a budget, how the project aligns with national policies, and risks to project success, among others.

2. This does not include proposals from NDAs for assistance with project development where the project is not linked to a Direct Access Entity (e.g., Barbados in January 2020).

\section{BIBLIOGRAPHY}

Adaptation Fund. n.d. "Readiness Grant Funding." Accessed February 9, 2021. https://www.adaptation-fund.org/apply-funding/grants/.

Ballesteros, A., S. Nakhooda, and J. Werksman, with K. Hurlburt and S. Kumar. 2010. Power, Responsibility, and Accountability: Re-thinking the Legitimacy of Institutions for Climate Finance. Final Report. Washington, DC: World Resources Institute. http://pdf.wri.org/working_papers/power_ responsibility_accountability_2009-11.pdf.

Bosma, M., M. de Hon, A. Douma, and D. Robben. 2018. Local Actors Ready to Act: Six Proposals to Improve Their Access to the Green Climate Fund. Amsterdam: Both ENDS; Washington, DC: Heinrich Böll Stiftung North America; Jakarta: Aksi! for gender, social and ecological justice; and Kathmandu: Prakriti Resources Centre. https://us.boell.org/sites/default/ files/local_actors_ready_to_act_-_six_proposals_to_improve_access_ to_the_gcf.pdf.

Brown, J., N. Bird, and L. Schalatek. 2010. "Direct Access to the Adaptation Fund: Realising the Potential of National Implementing Entities." Climate Finance Policy Brief No. 3. London: Overseas Development Institute and Heinrich Boll Stifting.

GCF (Green Climate Fund). 2020a. "Consideration of Accreditation Proposals." GCF/B.25/13/Rev.01. Meeting of the Board. Geneva: GCF. https://www. greenclimate.fund/sites/default/files/document/gcf-b25-13-rev01.pdf.

GCF. 2020b. "Enhancing Direct Access (EDA): Guidelines for EDA Project Development with the Green Climate Fund." Songdo, South Korea: GCF. https://www.greenclimate.fund/sites/default/files/document/edaguidelines.pdf.

GCF. 2020c. GCF Programming Manual, Songdo, South Korea: GCF. https:// www.greenclimate.fund/sites/default/files/document/gcf-programmingmanual.pdf.
GCF. 2020d. Ninth Report of the Green Climate Fund to the Conference of the Parties to the United Nations Framework Convention on Climate Change. Meeting of the Board. Virtual Meeting. https://www.greenclimate.fund/sites/ default/files/document/gcf-b27-17.pdf.

GCF. 2020e. "Project Preparation Facility (PPF) Guidelines." Songdo, South Korea: GCF. https://www.greenclimate.fund/sites/default/files/document/ ppf-guidelines_0.pdf.

GCF. 2020f. "Readiness and Preparatory Support Programme-Work Programme and Budget 2020-2021." GCF/B.26/05. Meeting of the Board. Virtual Meeting. https://www.greenclimate.fund/sites/default/files/ document/gcf-b26-05.pdf.

GCF. 2020g. "Review of the Simplified Approval Process Pilot Scheme." Meeting of the Board. Geneva: GCF. https://www.greenclimate.fund/sites/ default/files/document/gcf-b25-12.pdf.

GCF. 2020h. "Revision of the Structure and Operations of the Independent Technical Advisory Panel." Meeting of the Board. Geneva: GCF. https://www. greenclimate.fund/sites/default/files/document/gcf-b25-10.pdf.

GCF. 2020i. Readiness and Preparatory Support Programme Guidebook. Songdo, South Korea: GCF. https://www.greenclimate.fund/sites/default/ files/document/readiness-guidebook_1.pdf.

GCF. 2019a. "Review of the Initial Modalities of the Private Sector FacilityAddendum III Review of the Mobilizing Funds at Scale Pilot." GCF/B.23/12/ Add.03. Songdo, South Korea: GCF. https://www.greenclimate.fund/sites/ default/files/document/gcf-b23-12-add03.pdf.

GCF. 2019b. "Review of the Initial Modalities for the Private Sector FacilityAddendum IV Review of the Micro, Small and Medium-Sized Enterprise Pilot Programme." GCF/B.23/12/Add.04. Songdo, South Korea: GCF. https://www. greenclimate.fund/sites/default/files/document/gcf-b23-12-add04.pdf.

GCF. 2018. "Policy on Fees for Accredited Entities and Delivery Partners." GCF/B.19/29. Meeting of the Board. Songdo, South Korea: GCF. https://www. greenclimate.fund/document/gcf-b19-29.

GCF. 2017. "Operationalizing the Simplified Approval Process for Certain Activities, Including Small-Scale Activities." GCF/B.18/17. Meeting of the Board. Cairo: GCF. https://www.greenclimate.fund/sites/default/files/document/ gcf-b18-17.pdf.

GCF. 2016. "Request for Proposals: Enhancing Direct Access." Songdo, South Korea: GCF. https://www.greenclimate.fund/sites/default/files/page/2016eda-rfp.pdf. 
GCF. 2014a. "Guidelines for the Operationalization of the Fit-for-Purpose Accreditation Approach." Meeting of the Board. Bridgetown, Barbados: GCF. https://www.greenclimate.fund/document/gcf-b08-02.

GCF. 2014b. "Report of the Eighth Meeting of the Board, 14-17 October 2014." Meeting of the Board. Bridgetown, Barbados: GCF. https://www.greenclimate. fund/sites/default/files/document/gcf-b08-46.pdf.

GCF. 2011. "Governing Instrument for the Green Climate Fund," para 47. Songdo, South Korea: GCF. https://www.greenclimate.fund/sites/default/ files/document/governing-instrument.pdf.

Gonzales, M., D. Horikoshi, E. Mokgano, J. Puri, and C. Volonte. 2020. Independent Assessment of the GCF's Simplified Approval Process Pilot Scheme. Evaluation Report No. 7, June. Songdo, South Korea: Independent Evaluation Unit, Green Climate Fund.

IEU (Independent Evaluation Unit, Green Climate Fund). 2020. "Independent Evaluation Unit's Initial Assessment of the Secretariat's Review of the Simplified Approval Process Pilot Scheme." Meeting of the Board. Geneva: GCF. https://www.greenclimate.fund/sites/default/files/document/gcf-b25inf12.pdf.

IEU. 2019. Forward-Looking Performance Review of the Green Climate Fund (FPR). Evaluation Report No. 3 (2nd ed.), June. Songdo, South Korea: Green Climate Fund. https://ieu.greenclimate.fund/evaluations/fpr.

IEU. 2018. Independent Evaluation of Green Climate Fund Readiness and Preparatory Support Programme. Evaluation Report No. 1. Songdo, South Korea: Green Climate Fund.

Masullo, I., G. Larsen, L. Brown, and L. Dougherty-Choux. 2015. "'Direct Access' to Climate Finance: Lessons Learned by National Institutions." Working Paper. Washington, DC: World Resources Institute. http://www.wri. org/publication/direct-access.

Müller, B. 2011. "Enhanced Direct Access. Submission to the Transitional Committee on the Issue of Thematic Funding Windows (Workstreams II and III)." Oxford, United Kingdom: Oxford Institute for Energy Studies.

Murray, L., with B. Müller and L. Gomez-Echeverri. 2015. Enhanced Direct Access: A Brief History (2009-15), 0xford, United Kingdom: European Capacity Building Initiative. https://oxfordclimatepolicy.org/publications/documents/ EDA-Brief-History-published.pdf.

Omari-Motsumi, K., M. Barnett, and L. Schalatek. 2019. Broken Connections and Systemic Barriers: Overcoming the Challenge of the 'Missing Middle' in Adaptation Finance. Background Paper. Rotterdam, The Netherlands: Global Commission on Adaptation.
Orenstein, K., and 0. Reyes. 2017. Green Climate Fund: A Performance Check. Washington, DC: Friends of the Earth and Institute for Policy Studies. https:// foe.org/resources/green-climate-fund-performance-check/.

Soentoro, T., N. Rochaeni, and C. Coltman. 2016. The Green Climate Fund: A CSO Guide for Engagement and Local Access, Jakarta: Aksi! for gender, social and ecological justice; Bogor, Indonesia: The Samdhana Institute; and Amsterdam: Both ENDS. https://www.bothends.org/uploaded_files/ document/1CS0-guide_on_the_GCF_November_2016.pdf.

Ssendi, L, and N. Rai. 2016. Eight Things to Know about the GCF. London: International Institute for Environment and Development. https://pubs.iied. org/pdfs/10160llEE.pdf.

Tanner, T., H. Bishat, A. Quevedo, M. Malik, M. Nadiruzzaman, and S. Biswas. 2019. Enabling Access to the Green Climate Fund: Sharing Country Lessons from South Asia. Oxford, United Kingdom: Oxford Policy Management; and London: Overseas Development Institute. http://www.acclimatise.uk.com/ wp-content/uploads/2019/04/ACT-Green-Climate-Fund_Final.pdf.

Transitional Committee for the Design of the Green Climate Fund. 2011a. "Background Note: Overview of Financing Modalities and Addressing Methods Available to Manage Large-Scale Financial Resources from a Number of Sources." First Technical Workshop, May 27. Internal Draft. https:// unfccc.int/files/cancun_agreements/green_climate_fund/application/pdf/ tc_tsuws_ws3.pdf.

Transitional Committee for the Design of the Green Climate Fund. 2011b. "Revised Background Note: Direct Access." Second Meeting, June 29. TC-2/ WSIII/5. https://unfccc.int/files/cancun_agreements/green_climate_fund/ application/pdf/tc2_ws3_5_290611.pdf.

UNGA (United Nations General Assembly). 1992، "UNFCCC." Article 3, para 1. New York: UNGA. 


\section{ACKNOWLEDGMENTS}

The authors would like to thank all individuals who agreed to be interviewed for this paper as well as the GCF Secretariat, which provided valuable comments. We are also indebted to Louise Brown, who conducted several in-depth interviews and wrote a case study on the Environmental Investment Fund of Namibia, and to Andrea Rodríguez, who contributed a case study on Fundación Avina's GCF experience.

At World Resources Institute (WRI), we would like to thank the following colleagues who reviewed previous drafts of the paper or provided research support: Prashant Chandra, Giulia Christianson, Carolina Cuentas, Lorena Gonzalez, Shubham Gupta, Parvathi Preethan, Caitlin Smith, Lauren Sidner, Joe Thwaites, and Kareen Urrutia.

We would also like express our sincere appreciation to Germany's Federal Ministry for the Environment, Nature Conservation and Nuclear Safety, which provided the main funding for this publication. In addition, we are pleased to thank the French Development Agency and the C.S. Mott Foundation for their support to WRI's Finance Center.

Finally, we would like to acknowledge the institutional strategic partners that provide core funding to WRl: the Netherlands Ministry of Foreign Affairs, Royal Danish Ministry of Foreign Affairs, and Swedish International Development Cooperation Agency.

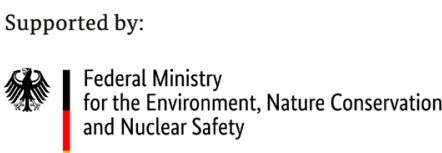

based on a decision of the German Bundestag

\section{ABOUT THE AUTHORS}

Molly Caldwell is a research analyst within WRI's Sustainable Finance Center.

Contact: molly.caldwell@wri.org

Gaia Larsen is a senior associate within WRI's Sustainable Finance Center. Contact: gaia.larsen@wri.org
ABOUT WRI

World Resources Institute is a global research organization that turns big ideas into action at the nexus of environment, economic opportunity, and human well-being.

\section{Our Challenge}

Natural resources are at the foundation of economic opportunity and human well-being. But today, we are depleting Earth's resources at rates that are not sustainable, endangering economies and people's lives. People depend on clean water, fertile land, healthy forests, and a stable climate. Livable cities and clean energy are essential for a sustainable planet. We must address these urgent, global challenges this decade.

\section{Our Vision}

We envision an equitable and prosperous planet driven by the wise management of natural resources. We aspire to create a world where the actions of government, business, and communities combine to eliminate poverty and sustain the natural environment for all people.

\section{Our Approach}

\section{COUNT IT}

We start with data. We conduct independent research and draw on the latest technology to develop new insights and recommendations. Our rigorous analysis identifies risks, unveils opportunities, and informs smart strategies. We focus our efforts on influential and emerging economies where the future of sustainability will be determined.

\section{CHANGE IT}

We use our research to influence government policies, business strategies, and civil society action. We test projects with communities, companies, and government agencies to build a strong evidence base. Then, we work with partners to deliver change on the ground that alleviates poverty and strengthens society. We hold ourselves accountable to ensure our outcomes will be bold and enduring.

\section{SCALE IT}

We don't think small. Once tested, we work with partners to adopt and expand our efforts regionally and globally. We engage with decision-makers to carry out our ideas and elevate our impact. We measure success through government and business actions that improve people's lives and sustain a healthy environment.

cc) creative (1) Copyright 2021 World Resources Institute. This work is licensed under the Creative Commons Attribution 4.0 International License.

cc) commons (i) To view a copy of the license, visit http://creativecommons.org/licenses/by/4.0/ 